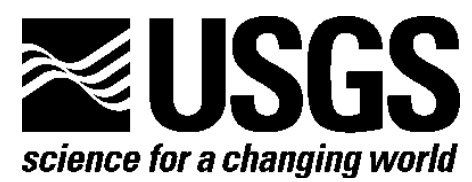

\title{
2010 Joint United States-Canadian Program to Explore the Limits of the Extended Continental Shelf Aboard U.S. Coast Guard Cutter Healy-Cruise HLY1002
}

August 2-September 6, 2010
Dutch Harbor to Barrow, Alaska

By Brian D. Edwards, Jonathan R. Childs, Peter J. Triezenberg, William W. Danforth, and Helen Gibbons

Open-File Report 2013-1067 


\section{U.S. Department of the Interior \\ SALLY JEWELL, Secretary}

\section{U.S. Geological Survey \\ Suzette M. Kimball, Acting Director}

U.S. Geological Survey, Reston, Virginia: 2013

For more information on the USGS-the Federal source for science about the Earth, its natural and living resources, natural hazards, and the environment-visit http://www.usgs.gov or call 1-888-ASK-USGS

For an overview of USGS information products, including maps, imagery, and publications, visit $h t t p: / / w w w . u s g s . g o v / p u b p r o d$.

To order this and other USGS information products, visit http://store.usgs.gov .

\section{Suggested citation:}

Edwards, B.D., Childs, J.R.,Triezenberg, P.J., Danforth, W.W., and Gibbons, Helen, 2013, 2010 Joint United StatesCanadian Program to explore the limits of the Extended Continental Shelf aboard U.S. Coast Guard Cutter HealyCruise HLY1002: U.S. Geological Survey Open-File Report 2013-1067, 26 p., plus appendixes.

Any use of trade, product, or firm names is for descriptive purposes only and does not imply endorsement by the U.S. Government.

Although this report is in the public domain, permission must be secured from the individual copyright owners to reproduce any copyrighted material contained within this report. 


\section{Contents}

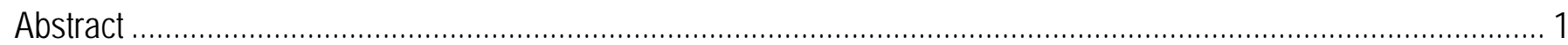

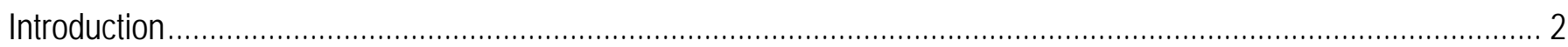

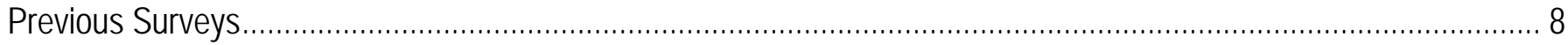

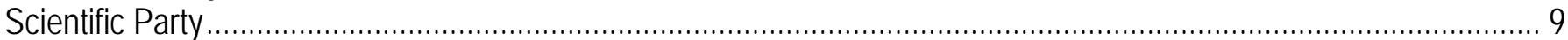

Underway Geophysical Data Acquisition and Processing .............................................................................

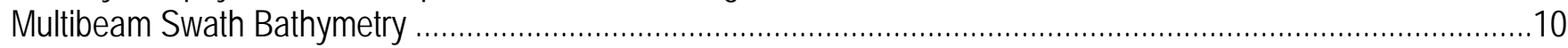

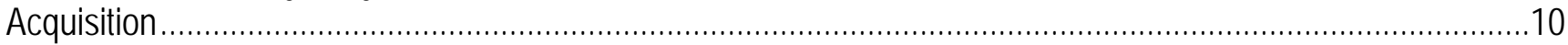

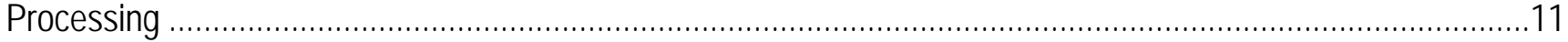

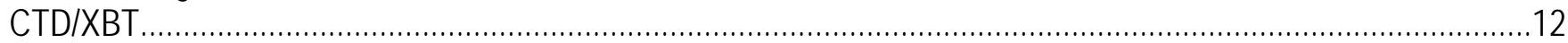

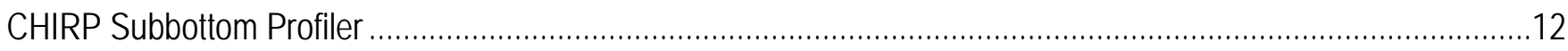

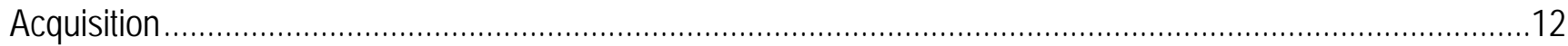

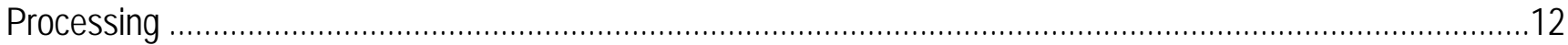

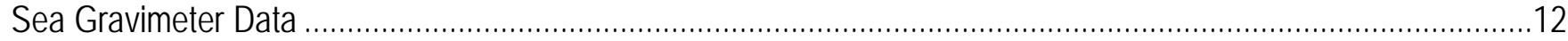

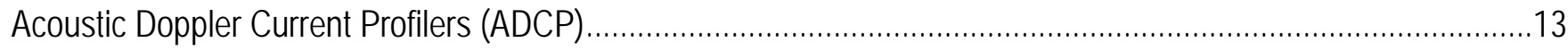

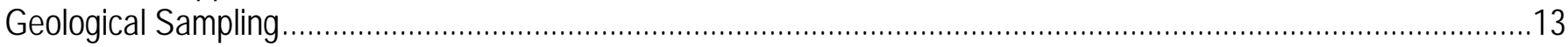

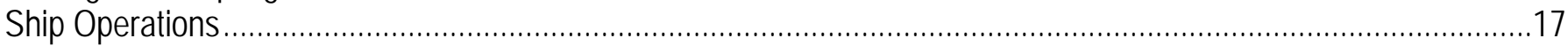

Data and Metadata

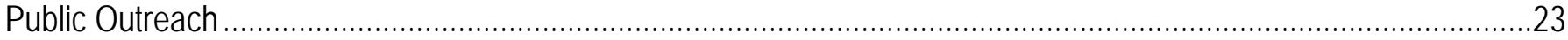

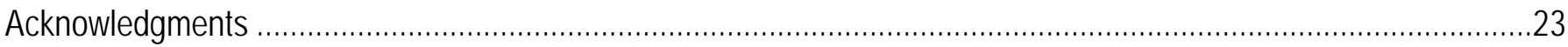

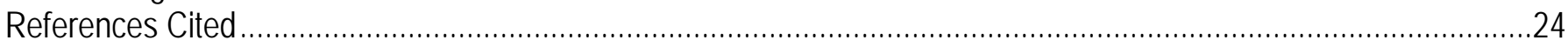

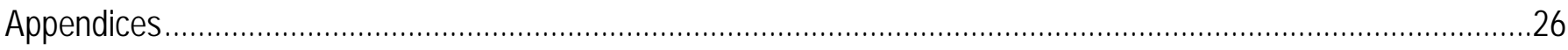

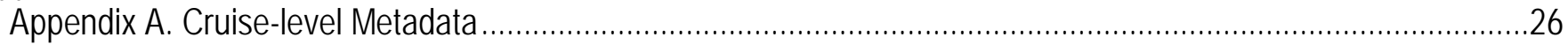

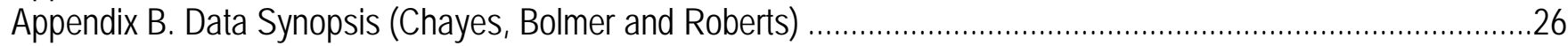

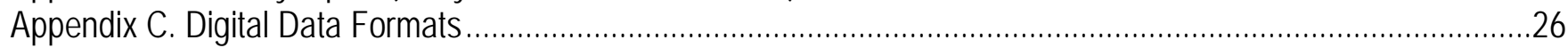

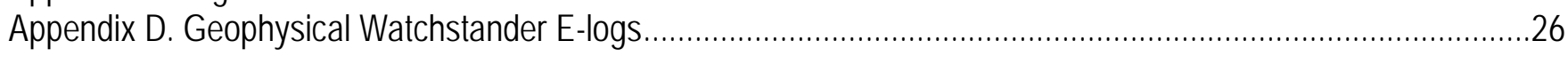

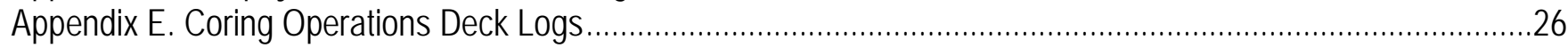

Appendix F. Water Sampling and Ocean Acidification Measurements ............................................................26

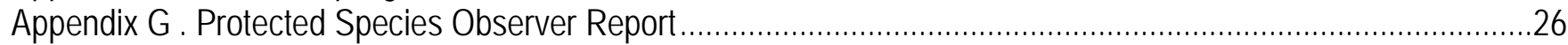

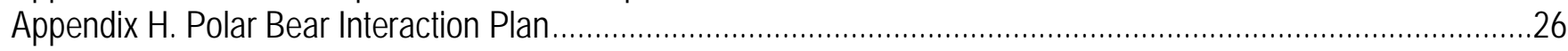

\section{Figures}

Figure 1. Photo showing U.S. Coast Guard Cutter Healy and Canadian Coast Guard icebreaker

Louis S. St-Laurent (Louis) breaking through ice in the Arctic Beaufort Sea ....................................................... 3

Figure 2. Figure illustrating the quality of Healy swath multibeam data coverage in 2008 ....................................... 4

Figure 3. Map showing tracklines for Healy (red) and Louis (yellow), and when both vessels

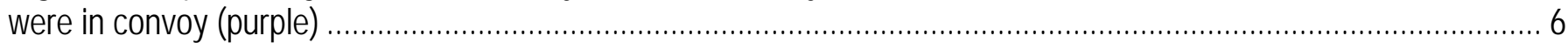

Figure 4. Map showing trackline locations for Healy (red) and Louis (yellow) ...................................................... 7

Figure 5. Photograph showing piston coring system on aft deck of Healy ........................................................ 14

Figure 6. Multibeam bathymetric model showing hydrate mound with core sites indicated by red dots..................... 15

Figure 7. Photograph showing gas hydrate recovery in core catcher of piston core 1P-1 ..................................... 15 


\section{Tables}

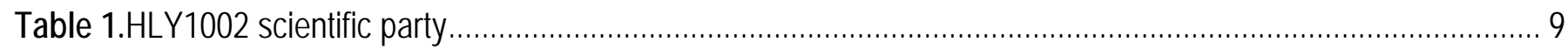

Table 2.Mis-ties (in milligals) at line crossings for two gravity meters (BGM-221, BGM-222) during four

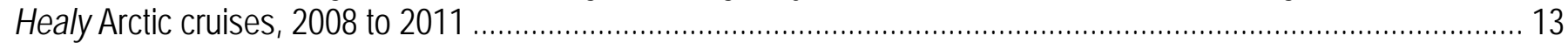

Table 3.Details of coring locations, recovery, and subsamples taken. .............................................................. 16

Table 4.Chronology of ship operations during conduct of HLY1002 and LSSL2012 ......................................... 17

Table 5.Time periods during which the Healy bathymetry and CHIRP subbottom data are embargoed

until further notice.

\section{Conversion Factors}

Inch/Pound to SI

\begin{tabular}{ccc}
\hline Multiply & By & To obtain \\
\hline & Mass & \\
\hline pound, avoirdupois $(\mathrm{lb})$ & 0.4536 & kilogram $(\mathrm{kg})$ \\
\hline & Length & \\
\hline mile, nautical (nmi) & 1.852 & kilometer $(\mathrm{km})$ \\
\hline
\end{tabular}

SI to Inch/Pound

\begin{tabular}{|c|c|c|}
\hline Multiply & By & To obtain \\
\hline \multicolumn{3}{|c|}{ Length } \\
\hline meter (m) & 3.281 & foot (ft) \\
\hline kilometer (km) & 0.6214 & mile (mi) \\
\hline kilometer (km) & 0.5400 & mile, nautical (nmi) \\
\hline meter (m) & 1.094 & yard (yd) \\
\hline
\end{tabular}

\begin{tabular}{lll} 
square kilometer $\left(\mathrm{km}^{2}\right)$ & 247.1 & acre \\
\hline meter per second $(\mathrm{m} / \mathrm{s})$ & Flow rate & \\
\hline & 3.281 & foot per second $(\mathrm{ft} / \mathrm{s})$ \\
\hline milligal $(\mathrm{mGal})$ & Acceleration & \\
\hline
\end{tabular}




\title{
2010 Joint United States-Canadian Program to Explore the Limits of the Extended Continental Shelf Aboard U.S. Coast Guard Cutter Healy-Cruise HLY1002
}

\author{
August 2-September 6, 2010 \\ Dutch Harbor to Barrow, Alaska
}

By Brian D. Edwards, Jonathan R. Childs, Peter J. Triezenberg, William W. Danforth, and Helen Gibbons

\begin{abstract}
In August and September 2010, the U.S. Geological Survey, in cooperation with Natural Resources Canada, Geological Survey of Canada, conducted bathymetric and geophysical surveys in the Beaufort Sea and eastern Arctic Ocean aboard the U.S. Coast Guard Cutter Healy. The principal objective of this mission to the high Arctic was to acquire data in support of a delineation of the outer limits of the U.S. and Canadian Extended Continental Shelf in the Arctic Ocean, in accordance with the provisions of Article 76 of the United Nations Convention on the Law of the Sea.

The Healy was accompanied by the Canadian Coast Guard icebreaker Louis S. St-Laurent. The scientific parties on board the two vessels consisted principally of staff from the U.S. Geological Survey (Healy), and the Geological Survey of Canada and the Canadian Hydrographic Service (Louis). The crew also included marine-mammal observers, Native-community observers, ice observers, and biologists conducting research of opportunity in the Arctic Ocean.

Despite interruptions necessitated by three medical emergencies, the joint survey proved largely successful. The Healy collected 7,201 trackline-kilometers of swath (multibeam) bathymetry (47,663 square kilometers) and CHIRP subbottom data, with accompanying marine gravity measurements, and expendable bathythermograph data. The Louis acquired 3,673 trackline-kilometers of multichannel seismic (airgun) deep-penetration reflection data along 25 continuous profiles, as well as 34 sonobuoy refraction stations and 9,500 trackline-kilometers of single-beam bathymetry. The coordinated efforts of the two vessels resulted in seismic-reflection-profile data that were of much higher quality and continuity than if the data had been acquired with a single vessel alone. The equipment-failure rate of the seismic equipment aboard the Louis was greatly reduced when the Healy led as the ice breaker. When ice conditions proved too severe to deploy the seismic system, the Louis led the Healy, resulting in much improved quality of the swath bathymetric and CHIRP subbottom data in comparison with data collected either by the Healy in the lead or the Healy working alone.
\end{abstract}


During periods when the Healy was operating alone (principally when the Louis was diverted for emergency medical evacuations or ship repairs), the Healy was able to deploy a piston-core-sampler (10 meters maximum potential recovery depending on configuration). The coring operations resulted in recovery of cores at five locations ranging from 2.4 to 5.7 meters in length from water depths ranging from 1,157 to 3,700 meters. One of these cores sited on the Alaskan margin recovered the first reported occurrence of methane hydrate from the Arctic Ocean.

Ancillary science objectives, including ice observations and deployment of ice-monitoring buoys and water-column sampling to measure acidification of Arctic waters were successfully conducted. The water-column sampling included using 10 full-ocean-depth, water-sampling casts with accompanying conductivity-temperature-depth measurements.

Except for the data deemed proprietary, data from the cruise have been archived and are available for download at the National Geophysical Data Center and at cooperating organizations.

Outreach staff and guest teachers aboard the two vessels provided near-real-time connection between the research activities and the public through online blogs, web pages, and other media.

\section{Introduction}

In August and September 2010, the U.S. Geological Survey (USGS), in cooperation with Natural Resources Canada, Geological Survey of Canada (GSC), conducted bathymetric and geophysical surveys in the Arctic Beaufort Sea and Canada Basin aboard the U.S. Coast Guard (USCG) Cutter Healy under the command of Capt. William (Bill) J. Rall. The principal objective of this mission (USCG identifier HLY1002; USGS Field Activity ID: H-3-10-AR) to the high Arctic was to acquire data in support of a delineation of the outer limits of the Extended Continental Shelf (ECS) beyond the 200-nmi-wide Exclusive Economic Zone (EEZ) in the Arctic Ocean in accordance with the provisions of Article 76 of the United Nations Convention on the Law of the Sea (see http://www.un.org/Depts/los/index.htm).

The Healy was accompanied by the Canadian Coast Guard icebreaker Louis S. St-Laurent (survey identifier LSSL2012; fig. 1). The scientific parties on board the two vessels consisted principally of staff from the USGS (Healy), and the GSC and the Canadian Hydrographic Service (Louis). The crew included marine-mammal observers, Native-community observers, ice observers, and oceanographers conducting research of opportunity in the Arctic Ocean. 


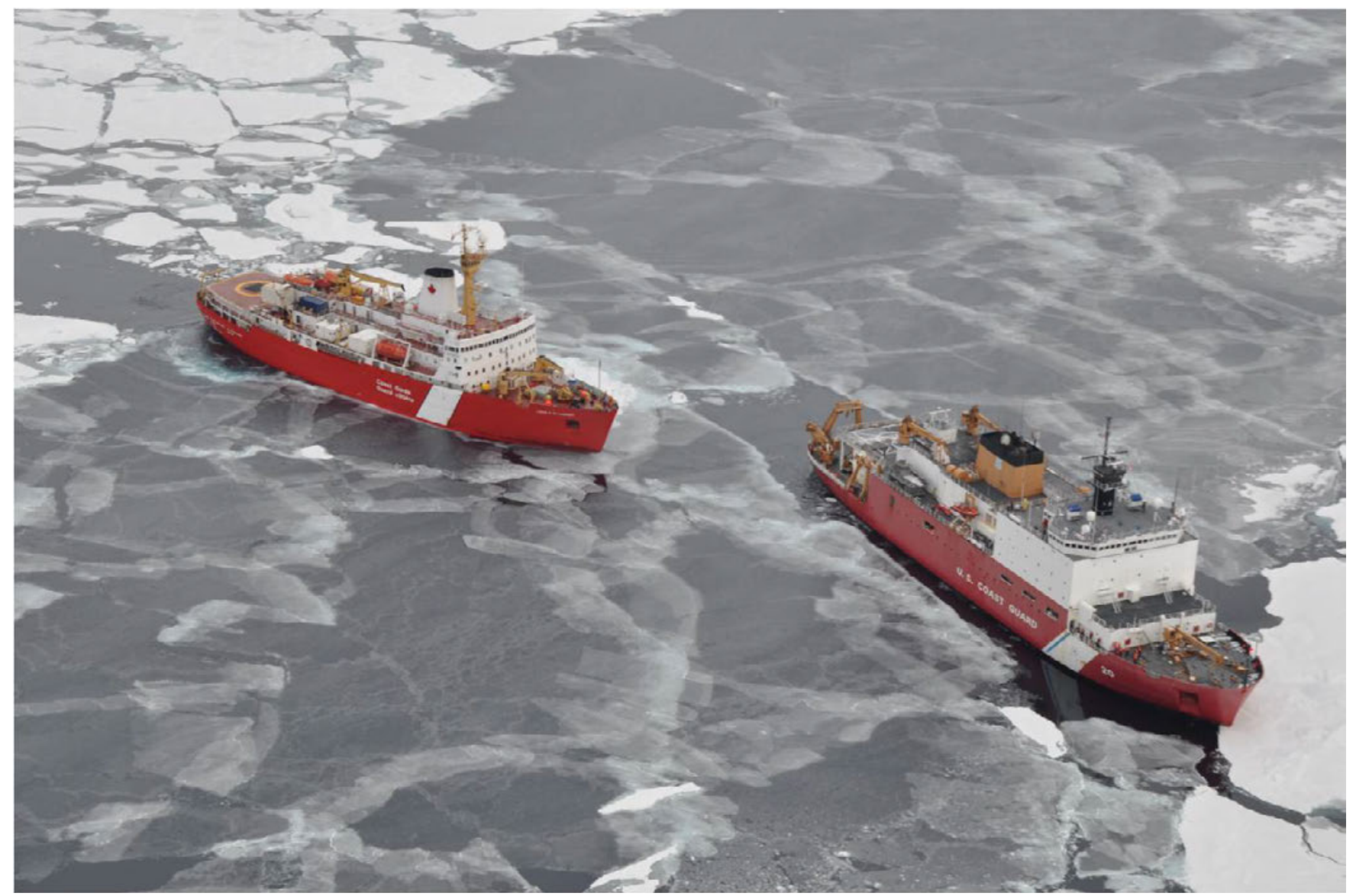

Figure 1. Photo showing U.S. Coast Guard Cutter Healy and Canadian Coast Guard icebreaker Louis S. StLaurent (Louis) breaking through ice in the Arctic Beaufort Sea.

The Healy departed Dutch Harbor, Alaska, on August 2, 2010; the Louis departed Kugluktuk, Nunavut, Canada, on August 6, 2010. Upon arrival in the operation area on August 8 (dates and times are in Coordinated Universal Time [UTC] “-7" unless noted otherwise), the Healy spent 2 days conducting a single-vessel multibeam bathymetric survey near longitude $141^{\circ} \mathrm{W}$, a zone of mutual interest to the U.S. and Canada. During this time, the Louis' scientific party deployed and tested airgun seismic-reflection gear in open water. The two vessels rendezvoused on August 11, and proceeded west to commence the seismic survey in the U.S. Exclusive Economic Zone (EEZ). However, after only a few hours, a crewmember on board the Louis was injured. The Louis suspended the seismic survey and transited to Tuktoyuktuk, Canada, for the medical evacuation (medevac). During this 2-day medevac by the Louis, the Healy conducted coring operations along the Beaufort margin and recovered one gravity core and two piston cores (see section, "Geological Sampling" for details). The two vessels rejoined on August 13 and conducted seismic surveys in the U.S. EEZ. When clear of the ice pack on August 16, the Healy left the Louis and transited to Barrow, Alaska, to pick up a replacement engineer and engine room parts for the Louis; the Healy rejoined the Louis on August 17, and the vessels continued joint operations within the U.S. EEZ. Throughout the joint operations, the Healy typically led the Louis during seismic-reflection profiling, while the Louis led the Healy when heavy ice conditions precluded deployment of the seismic-reflection system, incidentally resulting in significant improvement of the multibeam data quality (fig. 2). 


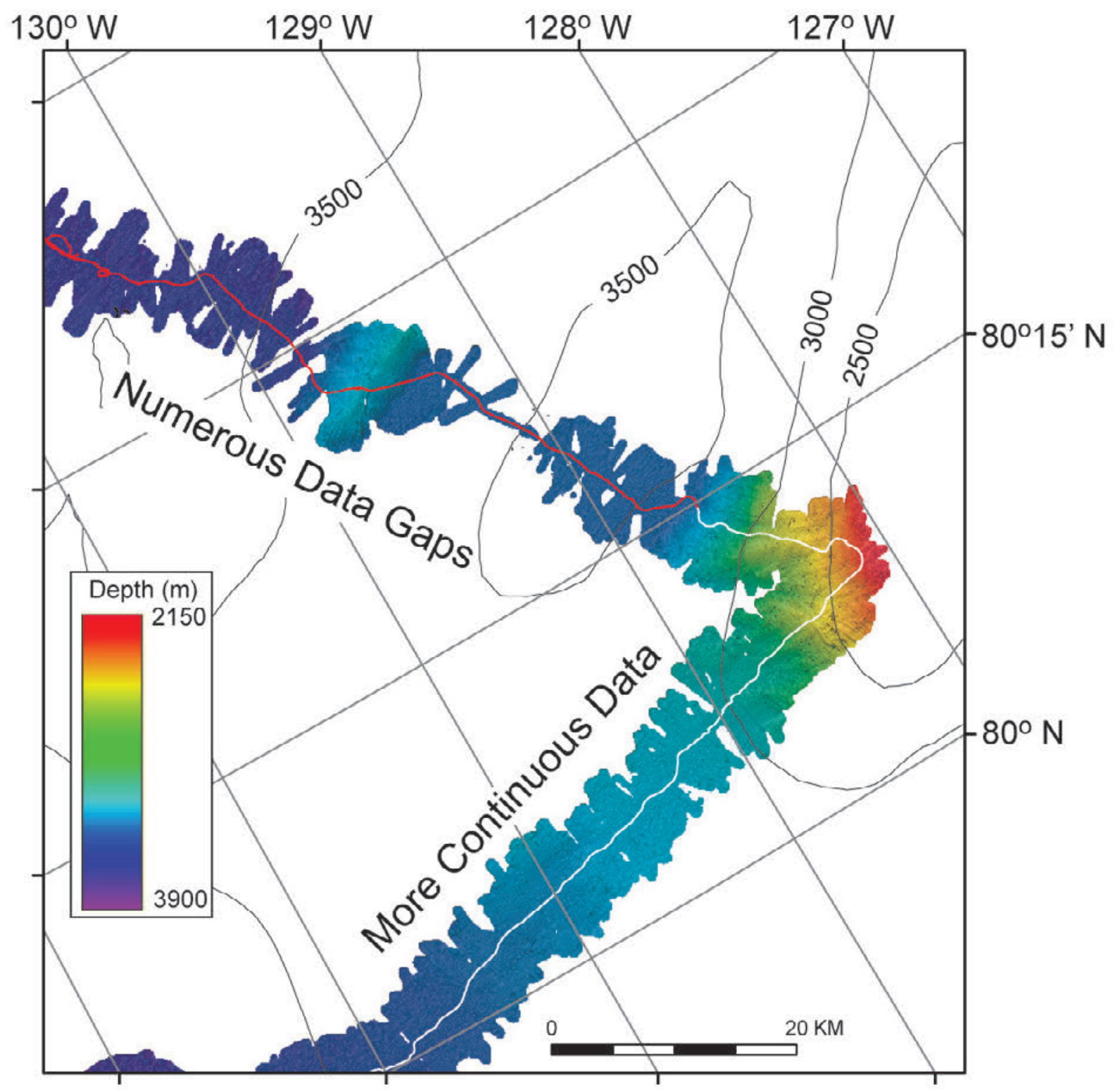

Figure 2. Figure illustrating the quality of Healy swath multibeam data coverage in 2008. Red trackline along the swath centerbeam identifies Healy breaking ice in front of Louis. White trackline along the centerbeam identifies Louis breaking ice in front of Healy. Note the marked improvement in swath continuity and width when Healy was the trailing vessel. 
Early in the morning on August 24, the Louis was forced to stop data collection owing to a damaged bearing on her port drive shaft assembly. After determining the nature of the damage and the Louis' safety, the Healy steamed alone to the site of the 2009 seamount discovery (Mayer and Armstrong, 2009), conducted a survey, and, unable to dredge because of ice conditions, recovered a piston core from a sediment pond on the upper flank of the seamount. The vessels rejoined midday on August 26, and continued joint operations until a medical emergency aboard the Louis on August 29 necessitated a second medevac. For 2 days, the ships convoyed south through heavy ice with the Healy typically leading the way. On August 30, shortly after clearing the heavy ice, an injury to a Healy crew member required transport to the Louis. The Louis then proceeded alone to Tuktoyuktuk, Canada, with both injured personnel. Between August 30 and September 2, the Healy conducted coring operations off the Canadian continental margin. The ships met again on September 3 and conducted joint seismic survey operations until early evening on September 4 when the two ships parted. The Healy returned to Barrow, Alaska, on September 6, and the Louis returned to Kugluktuk, Canada, on September 15 (fig. 3). Detailed trackline navigation for the two ships is presented in figure 4. Mosher and others (2011) compiled a cruise report for the Louis leg of the mission.

USGS activities in mapping the ECS are coordinated through the U.S. Extended Continental Shelf Task Force, which is composed of representatives from the USGS, the U.S. Department of State, the National Oceanographic and Atmospheric Administration (NOAA), and several other governmental agencies. Further information on the task force and its activities is posted at http://www.continentalshelf.gov/. 


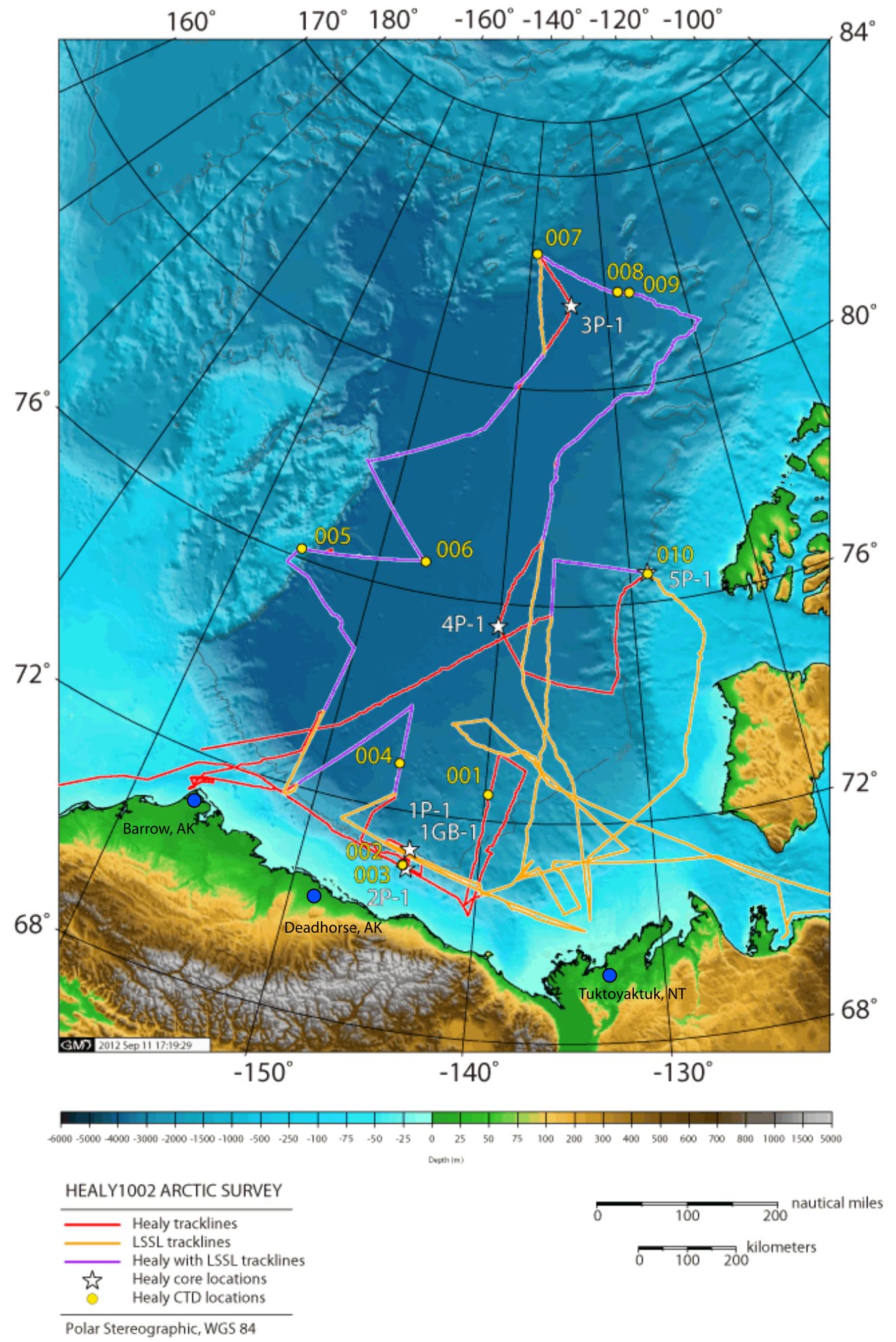

Figure 3. Map showing tracklines for Healy (red) and Louis (yellow), and when both vessels were in convoy (purple). Stars indicate the location of coring sites; circles indicate the location of conductivity-temperature-depth rosette casts (with station identification number) done from Healy. 

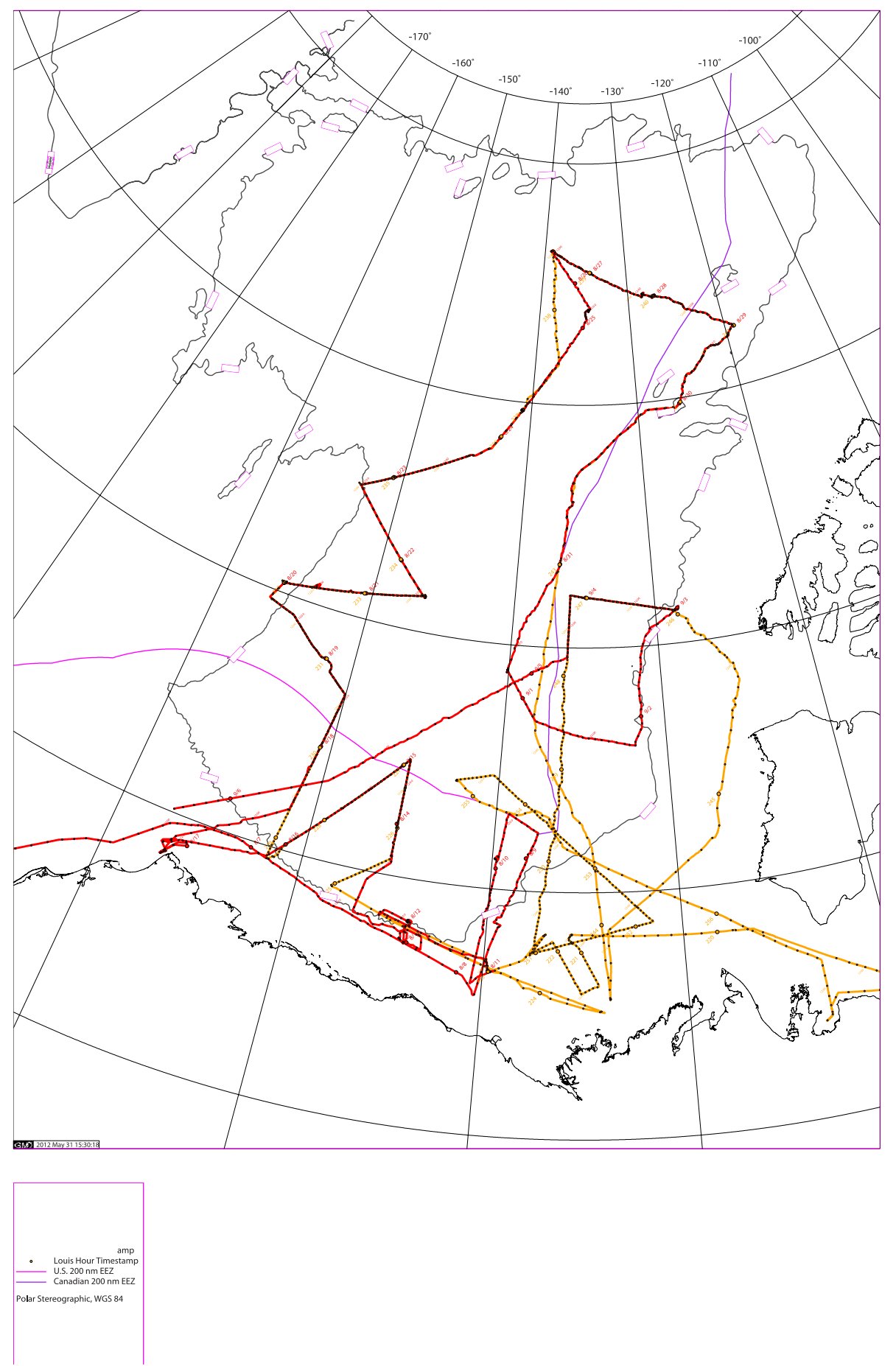

Figure 4. Map showing trackline locations for Healy (red) and Louis (yellow). Clicking on the figure will bring up a full resolution view of the tracklines revealing the relative position of each vessel. The tracks for both ships are annotated every hour - Healy tracks are annotated with month/day and Louis tracks are annotated with day-of-theyear (the conventions used to record dates on the respective vessels). U.S. and Canadian EEZ boundaries are shown for reference. NOTE: the swath bathymetry and subbottom profile data acquired during HLY1002 within the Canadian 200-nautical-mile-wide EEZ are proprietary and public release is not authorized at this time. See section, "Data and Metadata" for further details. 


\section{Previous Surveys}

This joint U.S.-Canadian program, started in 2008, was built on earlier work by both countries. The USGS (with Canadian participation) conducted geophysical surveys in 1988, 1991, and 1992 in the Arctic aboard the USCG icebreaker Polar Star (Grantz and others, 2004).

Seismic reflection and refraction data were acquired in the Arctic from the Healy in 2005 (cruise HLY0503; Coakley and others, 2005) and 2006 (cruise HLY0602). These surveys were funded by the National Science Foundation, and were not associated with or funded through the U.S. Extended Continental Shelf Task Force. Further details are available at Coakley and others (2005) and posted at the following URLs:

http://icefloe.net/healy-2005-cruise-reports

http://icefloe.net/healy-2006-cruise-reports

In 2003, 2004, 2007, and 2008, the University of New Hampshire Center for Coastal and Ocean Mapping and the NOAA Joint Hydrographic Center conducted a series of bathymetric surveys with the Healy funded by the U.S. ECS program (Mayer, 2003, 2004; Mayer and Armstrong, 2007, 2008).

In 2007, the GSC and the Canadian Hydrographic Service conducted geophysical and bathymetric surveys aboard the Louis in the Arctic in single-vessel mode. As of March, 2013, the data from this survey are proprietary.

The joint U.S.-Canadian Arctic program was initiated in 2008 (Hutchinson and others, 2009; Jackson and DesRoches, 2010; Childs and others, 2012) and continued in 2009 (Mayer and Armstrong, 2009; Mosher and others, 2009). After the 2010 expedition reported here, a fourth and final joint survey was conducted in 2011 (Mayer and Armstrong, 2011; Mosher, 2012). 


\section{Scientific Party}

Members of the 2010 HLY1002 scientific party are listed in table 1 with each individual's institutional association and position on the cruise.

Table 1. HLY1002 scientific party.

\begin{tabular}{|c|c|c|}
\hline \multicolumn{3}{|c|}{ HLY1002 science party } \\
\hline Name & Institution & Position \\
\hline Brian D. Edwards & USGS & Chief Scientist \\
\hline Kwasi Addae & MRAG & Protected Species Observer \\
\hline Sarah Ashworth & MRAG & Protected Species Observer \\
\hline Tom Bolmer & WHOI/LDEO/ NSF & Data Specialist \\
\hline Michel Bourdeau & Captain, Canadian Coast Guard & Canadian command liaison \\
\hline Dale Chayes & LDEO/NSF & Science Systems \\
\hline Jonathan Childs & USGS & USGS liaison (aboard Louis) \\
\hline Erin Clark & Canadian Ice Service - Environment Canada & Ice Services Specialist \\
\hline Pablo Clemente-Colon & NIC/NOAA & Scientist \\
\hline Pete dal Ferro & USGS & Engineering Technician \\
\hline William Danforth & USGS & Scientist \\
\hline Christopher Dufore & USGS & Scientist \\
\hline Helen Gibbons & USGS & Scientist \\
\hline Donny Graham & ESU & Internet Technician \\
\hline Ralph Kaleak & BASC & Native Community Liaison \\
\hline Sherwood Liu & USF & Scientist \\
\hline Joshua Miller & NIC/USCG & Ice Analyst/Buoy Technician \\
\hline Thomas O'Brien & USGS & Scientist \\
\hline Caryn Panowicz & NIC & Ice analyst (aboard Louis) \\
\hline Mark Patsavas & USF & Scientist \\
\hline Justin Pudenz & MRAG & Protected Species Observer \\
\hline Steve Roberts & NCAR/LDEO/ NSF & Computer engineer \\
\hline William Schmoker & PolarTREC Arctic Research Consortium & Teacher outreach \\
\hline Caroline Singler & NOAA/Teacher- at-Sea & Teacher outreach \\
\hline Andrew Stevenson & USGS & Scientist \\
\hline David Street & Canadian Hydrographic Service & Hydrogropher \\
\hline Peter Triezenberg & USGS & Scientist \\
\hline Jenny White & USGS & Engineering Technician \\
\hline
\end{tabular}

\begin{tabular}{l|l}
\multicolumn{1}{c|}{ Acronym } & \multicolumn{1}{c}{ Institution } \\
\hline BASC & Barrow Arctic Science Consortium \\
\hline ESU & Electronic Systems Support Unit Seattle \\
\hline LDEO & Lamont-Doherty Earth Observatory, Columbia University \\
\hline MRAG & MRAG Americas \\
\hline NCAR & NOAA National Center for Atmospheric Research \\
\hline NIC & NOAA National Ice Center \\
\hline NOAA & National Oceanic and Atmospheric Association \\
\hline NSF & National Science Foundation \\
\hline USCG & U.S. Coast Guard \\
\hline USF & University of South Florida \\
\hline USGS & U.S. Geological Survey \\
\hline WHOI & Woods Hole Oceanographic Institution
\end{tabular}




\section{Underway Geophysical Data Acquisition and Processing}

Complete details of all geophysical, oceanographic, and meteorologic sensors aboard the Healy are presented in appendix $\mathrm{C}$, the onboard data synopsis is by technical staff members Dale Chayes, Steve Roberts, and Tom Bolmer.

During the cruise, data acquisition was synchronized to Greenwich Mean Time (equivalent to Coordinated Universal Time [UTC]). During two-ship operations, both vessels synchronized their clocks to UTC minus 7 hours (Pacific Daylight Time). Prior to the rendezvous with the Louis and following the final separation from the Louis, the Healy's ship clocks were set to UTC minus 8 hours (Alaska Daylight Time).

The Healy is equipped with a Kongsberg EM122 echosounder and a Knudsen 320 B/R bottom sounder, both hull mounted. Two Bell BGM-3 gravimeters were installed for the cruise in the vessel's

IC Gyro compartment. The quality of these datasets varied widely, depending on ice conditions and ship operations.

Data acquisition was monitored continuously throughout the cruise by scientific and technical watchstanders. The scientific watchstanders worked 8-hour watches (00:00-08:00, 08:00-16:00, and 16:00-24:00, local ship time) and were responsible for monitoring all underway equipment. During each watch, the watchstanders would adjust acquisition parameters for the Kongsberg and Knudsen systems, ensure that data files were being updated, note anomalies or changes in operations in the e-log, and inform the ship technical staff when an instrument malfunctioned.

Although minor malfunctions occasionally interrupted data acquisition, these data gaps typically occurred for no more than a few minutes. No major instrument failures of the multibeam or subbottom profilers occurred during the cruise.

\section{Multibeam Swath Bathymetry}

Acquisition

Multibeam echosounder data were collected onboard the Healy using a Kongsberg EM122 echosounder that is permanently installed on the hull. Data were acquired on a PC workstation running the SIS software acquisition package supplied by Kongsberg. Each sensor offset, such as the location of the navigation antennas and the actual location of the motion reference unit, were measured from a common reference point. These values were entered to the data acquisition system prior to survey operations, and ensured that the sensor data streams were properly applied to the multibeam data during acquisition. Raw data were saved to disk in Kongsberg’s “raw.all” format (Kongsberg, 2010).

Primary navigation and motion data (heave, pitch, roll, heading) were measured with an Applanix POS/MV-320 system, and these data were integrated with the multibeam data acquisition, ensuring that the ship's motion was compensated for and applied to the data in real time. Navigational data from the POS/MV-320 were incorporated in the multibeam data acquisition as well, and stored in the raw data files. Sound velocity at the keel (for the beamformer) was calculated from seawater temperature and conductivity as measured by an installed SeaBird SBE-45 Thermosalinograph. To ensure proper beam ray tracing through the water column during data acquisition, sound-velocity profiles were constructed from two sources: (1) data acquired by profiling systems deployed during the cruise, and (2) historical data. The deployed systems included expendable bathythermograph (XBT), conductivity-temperature-depth (CTD), and expendable conductivity-temperature-depth (XCTD) profiling systems; historical data were obtained from the Levitus database (see http://iridl.ldeo.columbia.edu/SOURCES/.LEVITUS94/.dataset_documentation.html/). Data were 
corrected for variations of sound velocity in the water column and for the draft of the multibeam transmit-receive arrays in real time by the sonar data-acquisition program, and were then saved to the raw data files.

\section{Processing}

The raw data files were brought into the CARIS HIPS and SIPS 7.0 software (see http://www.caris.com/products/hips-sips/) using the CARIS conversion wizard, which converts all data packets in the raw Kongsberg multibeam files to the internal CARIS format. Before the conversion was run, a vessel file named Healy2010_EM122.hvf was created with roll, pitch, heave, gyro, navigation and swath 1 activated within the file. This file is necessary for two reasons: (1) all converted files are stored in a named hierarchy that includes the vessel file name, and (2) the file identifies to CARIS the sensors that are to be parsed from the raw input file for visual inspection after conversion. As mentioned in section, “Acquisition,” the SIS data acquisition program applied the heave, pitch, and roll data during acquisition; therefore, during the data conversion, the values for heave, pitch, roll, heading, and navigation were carried over into the converted CARIS files but not applied by the conversion process.

The converted data were stored on disk in a project folder (HealyAugust2010) that contains a subfolder named after the vessel file (Healy2010_EM122). That subfolder was further subdivided into Julian days, with each Julian-day folder containing all the line files for that day. For example, the Healy 1002 CARIS database has this structure: HealyAugust2010/Healy2010_EM122/2010-219/line files.

The raw data were stored in filenames of the form LLLL_YYYYMMDD_HHMMSS_Healy.all, where LLLL is the line number, YYYYMMDD is the calendar date and HHMMSS is the time in UTC. The raw data were then transferred from the data server and converted to CARIS-readable format. Each 30-minute interval of the Julian day was saved with a unique file_id in the corresponding project and vessel folders.

The Universal North Polar Stereographic Projection system was used for the project map projection. A central meridian of $-160^{\circ}$, latitude of true-scale $75^{\circ} \mathrm{N}$., and the WGS84 ellipsoid were selected for the projection parameters to correspond with parameters used by other projects in the Arctic Law of the Sea program. The file mapdef.dat, was replaced with a file that resides in a HIPS/System directory to ensure that the Universal North Polar Stereographic Projection would plot correctly.

Swath editing first was performed manually to each line, and obviously erroneous soundings were removed from the data files. Auxiliary-sensor-data were not cleaned during processing because those corrections were applied during acquisition. Sound-velocity corrections were not applied during processing because these corrections were applied during the data-acquisition stage as well. Because tide loading is a mandatory step in the CARIS processing workflow, a file zerotide.tid was created for this survey with a zero tide value for the entire cruise, as no tidal data were available for the Arctic. Navigation and tide corrections were applied to each observed and edited sounding as the last step in the processing workflow.

A CARIS BASE surface (grid) then was generated as a first view to visually inspect the data quality and to further remove bad soundings if needed. A horizontal resolution of $100 \mathrm{~m}$ per grid node was used when creating the grid.

Each grid was examined (using the swath editor, if necessary) to identify and remove erroneous soundings that may have been missed on the first editing pass. Once these soundings were removed from the data files, the grid was recomputed to reflect the editing. Data gaps ("holes") in the grid were then filled by a mean-value interpolation using the average of neighboring pixels. 
The final step in the processing work flow was to convert the grid into Fledermaus dtm/geo files for three-dimensional presentation of the collected data.

\section{CTD/XBT}

XBT casts were conducted at regular intervals throughout the cruise to establish sound-velocity profiles required to correct the multibeam bathymetry. Additionally, CTD casts, during which water samples also were collected, were made as time and operational schedules permitted. The CTD and XBT data acquisition is detailed in tables A.2 and A.3 of appendix B.

\section{CHIRP Subbottom Profiler}

\section{Acquisition}

The Knudsen BR-320 bottom sounder and subbottom profiler functioned well in the ice, maintaining a lock on the bottom even under heavy ice conditions. The primary effect of heavy ice was to introduce gaps in the profile data.

In addition to creating high-resolution subbottom reflection profiles using a frequencymodulated ("chirp") source signal, the Knudsen system tracks the bottom return, and generates a digital single-beam depth record. Unlike the Kongsberg system, however, which uses a dynamic soundvelocity-profile model to transform travel time to true depth, the Knudsen system uses a constantvelocity factor of 1,500 m/s. Therefore, digital depths from the Knudsen differ from and are less accurate than the Kongsberg centerbeam depths. The Healy also was equipped with an ODEC Bathy2000 fathometer, which was not used during HLY1002.

Processing

See http://sioseis.ucsd.edu/notes.html for a discussion of Knudsen CHIRP systems and signal processing implemented on the Healy.

\section{Sea Gravimeter Data}

Two Bell BGR-3 gravimeters (BGM-221 and BGM-222) were installed on the Healy for the entire 2010 survey. Details of the installation and operation of these instruments are presented in appendix D of Mayer and Armstrong (2008).

The two gravimeters operated continuously during the period from the Healy's initial departure from Seattle, Washington, on May 16, 2010, until her return on October 12, 2010. Drift measurements for the two instruments were estimated over approximately 280 days, during which time the BGM-221 drifted imperceptibly (0.12 milligal) and the BGM-222 drifted slightly more (12.3 milligal).

The gravity field crossing errors in milligals, compared with those on other Healy cruises for the two gravimeters, are listed in table 2. 
Table 2. Mis-ties (in milligals) at line crossings for two gravity meters (BGM-221, BGM-222) during four Healy Arctic cruises, 2008 to 2011.

\begin{tabular}{|l|c|c|c|c|c|c|c|c|}
\hline & HLY-08-221 & HLY-09-221 & HLY-10-221 & HLY-11-221 & HLY-08-222 & HLY-09-222 & HLY-10-222 & HLY-11-222 \\
\hline HLY-08-221 & 0.07 & 0.07 & 0.12 & 0.16 & 0.19 & -0.03 & 0.34 & 0.17 \\
\hline HLY-09-221 & 0.08 & 0.08 & -0.08 & -0.04 & 0.05 & -0.17 & 0.18 & 0.02 \\
\hline HLY-10-221 & -0.12 & 0.08 & 0.01 & 0.01 & -0.03 & -0.21 & 0.13 & -0.02 \\
\hline HLY-11-221 & -0.16 & 0.04 & 0.02 & 0.02 & 0.12 & -0.06 & 0.28 & 0.11 \\
\hline HLY-08-222 & -0.19 & -0.05 & 0.03 & -0.12 & 0.05 & 0.05 & 0.29 & 0.07 \\
\hline HLY-09-222 & 0.03 & 0.17 & 0.21 & 0.06 & 0.03 & 0.03 & 0.46 & 0.25 \\
\hline HLY-10-222 & -0.34 & -0.18 & -0.13 & -0.28 & -0.29 & -0.46 & 0.11 & 0.11 \\
\hline HLY-11-222 & -0.17 & -0.02 & 0.02 & -0.11 & -0.07 & -0.25 & 0.04 & 0.04 \\
\hline
\end{tabular}

\section{Acoustic Doppler Current Profilers (ADCP)}

Both of the hull-mounted ADCPs (75 kilohertz and 150 kilohertz) operated continuously throughout the cruise. No interests in the ADCP measurements have been identified, on or off the ship, and, accordingly, these data were subjected to no further examination, processing, or quality control. The data are freely available for download and analysis by contacting the authors.

\section{Geological Sampling}

Throughout the 2010 cruise, the Healy occasionally operated alone — principally when the Louis was otherwise engaged in medevac transits or repairs. At these times, gravity and piston coring operations were conducted. As shown in figure 3 and detailed in table 3, coring occurred at five locations; the piston core system is shown in figure 5 . One significant finding from these cores occurred at site $1 \mathrm{P}-1$, where gas hydrate was recovered at a subbottom depth of $5.7 \mathrm{~m}$. This is the first report of a methane hydrate sample recovered from the Arctic Basin-Ocean (Edwards and others, 2011). 


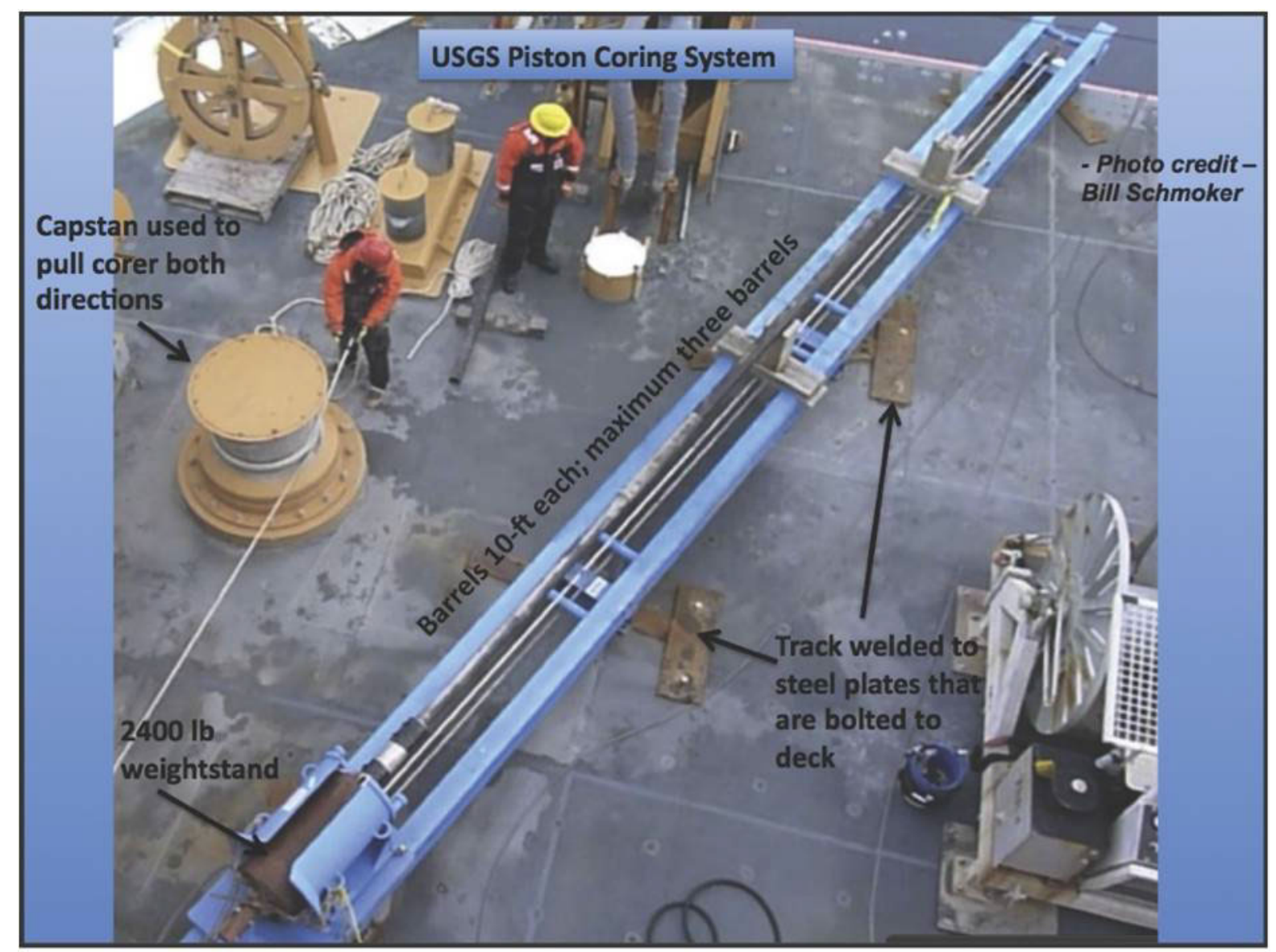

\section{USGS Piston Coring System on USCGC Healy's Fantail}

Figure 5. Photograph showing piston coring system on aft deck of Healy.

The original coring target for site 1P-1 was a seafloor high on the continental slope northeast of Prudhoe Bay, Alaska, that had been identified from USGS multichannel seismic-reflection data acquired in 1977 (Grantz and others, 1982). Multibeam data collected during HLY1002, however, revealed a conical mound in the area of the original target (fig. 6), and the final coring site was shifted to the flank of that mound (water depth 2,538 m). The gas hydrate had a nodular and vein-filling morphology (fig. 7). Although the hydrate was not preserved, residual gas recovered from the core liner contained more than 95 percent methane by volume when corrected for atmospheric contamination (Hart and others, 2011). Other analyses and descriptions of these cores were presented by Edwards and others (2011) and Wan and others (2011). 


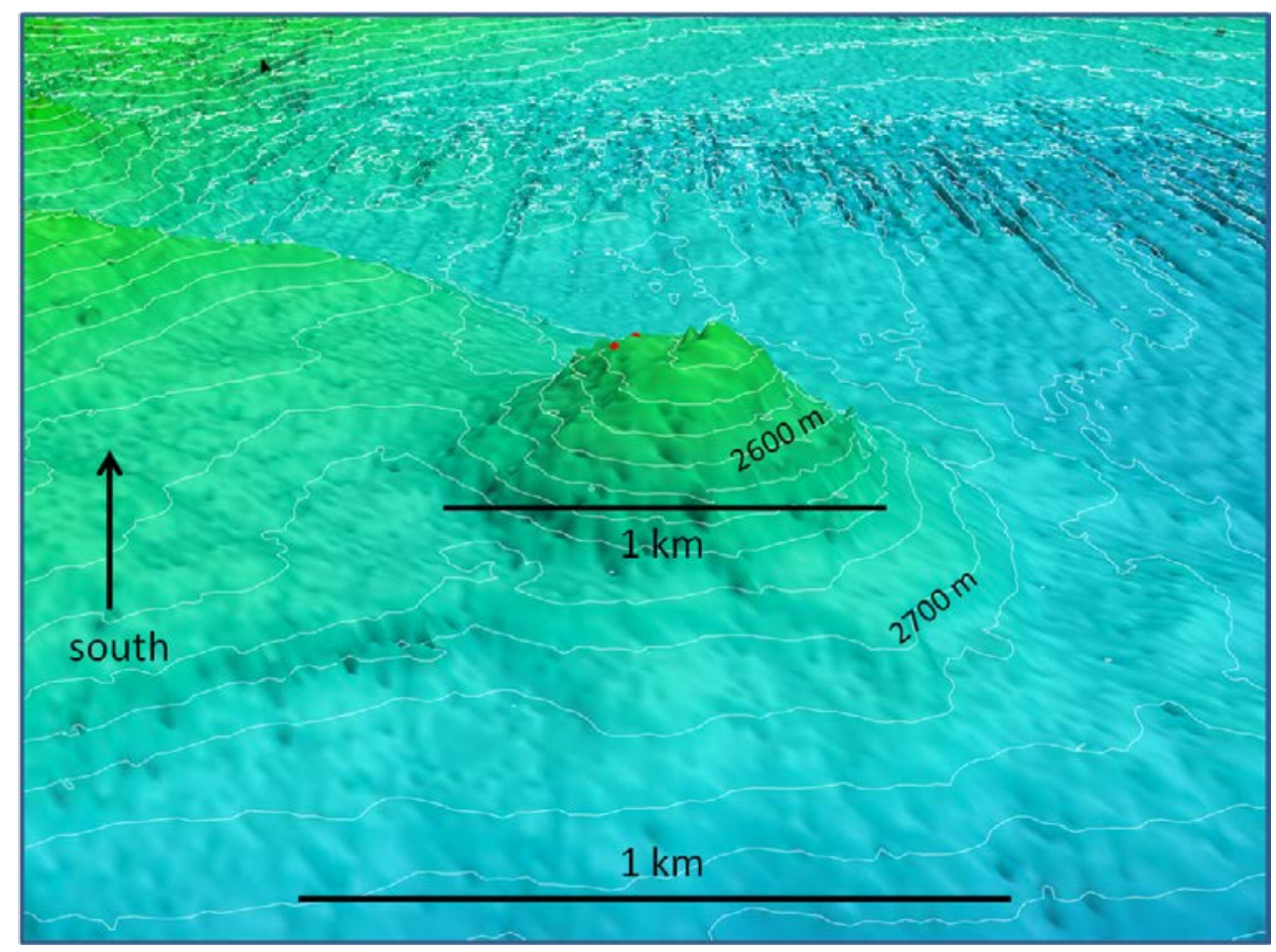

Figure 6. Multibeam bathymetric model showing hydrate mound with core sites indicated by red dots.

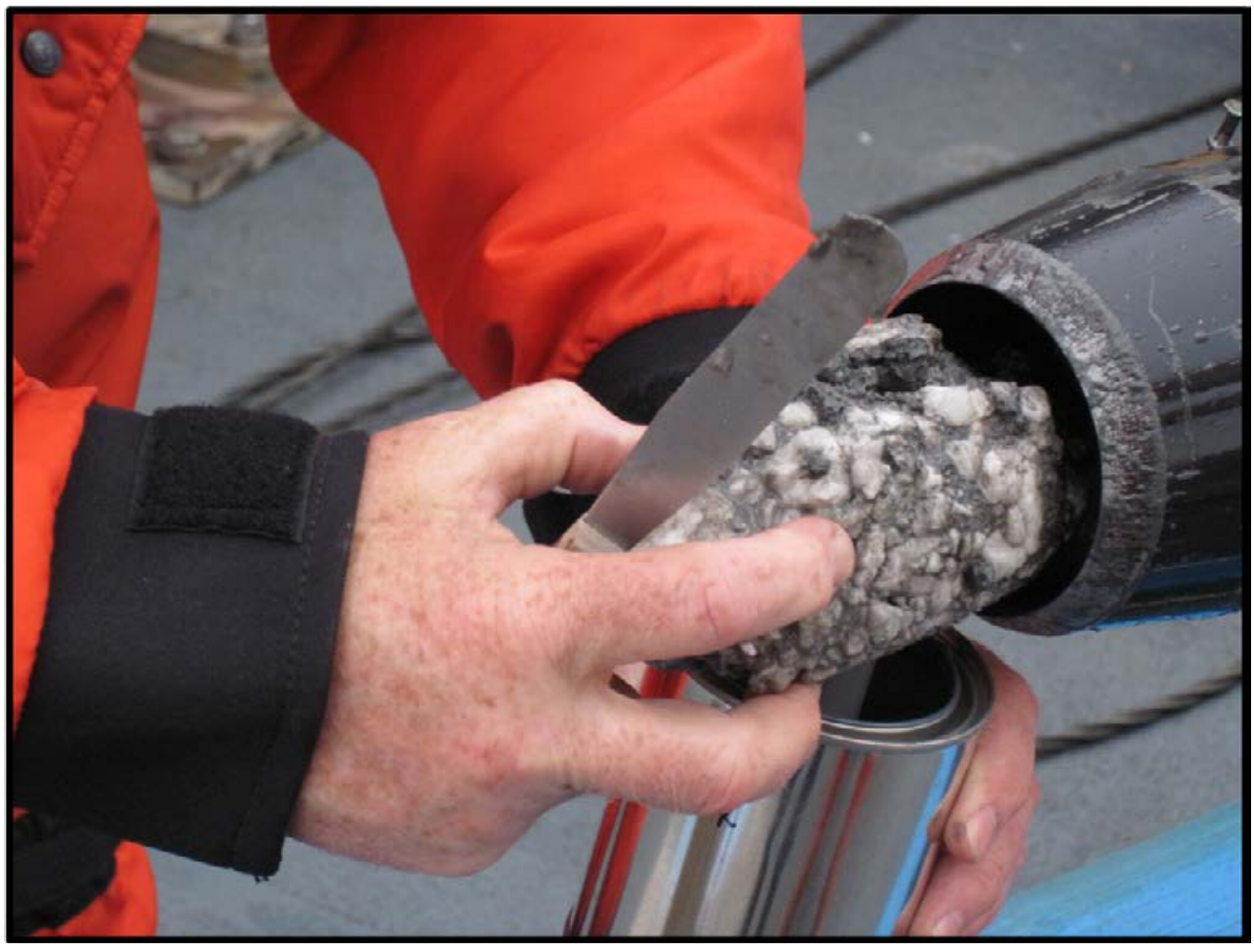

Figure 7. Photograph showing gas hydrate recovery in core catcher of piston core 1P-1. 
Table 3. Details of coring locations, recovery, and subsamples taken.

\begin{tabular}{|c|c|c|c|c|c|c|c|c|c|}
\hline SESAR_ISGN & Sample ID & Latitude $\mathbf{N}$. & $\begin{array}{c}\text { Longitude } \\
\text { W. }\end{array}$ & $\begin{array}{c}\text { Water Depth } \\
\text { (m) }\end{array}$ & Equipment & Day & $\begin{array}{c}\text { Time } \\
\text { (UTC) }\end{array}$ & $\begin{array}{l}\text { Recovery } \\
\text { (cm) }\end{array}$ & Subsamples \\
\hline ECS003000 & $1 \mathrm{~GB}-1$ & $71.31767^{\circ}$ & $143.99828^{\circ}$ & 2530 & GB & $8 / 11 / 2010$ & $21: 30$ & 240 & CC, MFx \\
\hline ECS003001 & $1 \mathrm{P}-1$ & $71.31747^{\circ}$ & $143.99970^{\circ}$ & 2538 & $\mathrm{P}$ & $8 / 12 / 2010$ & $3: 15$ & 571 & CA,CC,MFx, MFs \\
\hline ECS003002 & 1TC-1 & $71.31747^{\circ}$ & $143.99970^{\circ}$ & 2538 & $\mathrm{TC}$ & $8 / 12 / 2010$ & $3: 15$ & 83 & CC,CA,MFx \\
\hline ECS003003 & $2 \mathrm{P}-1$ & $70.95910^{\circ}$ & $144.05238^{\circ}$ & 1157 & $\mathrm{P}$ & $8 / 12 / 2010$ & $11: 19$ & 302 & CC,CA,MFx \\
\hline ECS003004 & 2TC-1 & $70.95910^{\circ}$ & $144.05238^{\circ}$ & 1157 & TC & $8 / 12 / 2010$ & $11: 19$ & 79 & CC,CA,MFx \\
\hline ECS003005 & $3 \mathrm{P}-1$ & $81.57966^{\circ}$ & $134.47790^{\circ}$ & 3070 & $\mathrm{P}$ & $8 / 25 / 2010$ & $10: 46$ & 546 & CC,CA(2),MFx, Tx \\
\hline ECS003006 & 3TC-1 & $81.57966^{\circ}$ & $134.47790^{\circ}$ & 3070 & TC & $8 / 25 / 2010$ & $10: 46$ & NR & $\mathrm{CA}(2)$ \\
\hline ECS003007 & $4 \mathrm{P}-1$ & $75.58413^{\circ}$ & $140.09293^{\circ}$ & 3700 & $\mathrm{P}$ & $8 / 31 / 2010$ & $12: 54$ & 337 & CA,MFx \\
\hline ECS003008 & 4TC-1 & $75.58413^{\circ}$ & $140.09293^{\circ}$ & 3700 & $\mathrm{TC}$ & $8 / 31 / 2010$ & $12: 54$ & NR & CA \\
\hline ECS003009 & $5 \mathrm{P}-1$ & $76.54377^{\circ}$ & $128.62745^{\circ}$ & 2081 & $\mathrm{P}$ & $9 / 2 / 2010$ & $18: 36$ & 496 & WSs,MFx,CA \\
\hline ECS003010 & 5TC-1 & $76.54377^{\circ}$ & $128.62745^{\circ}$ & 2081 & TC & $9 / 2 / 2010$ & $18: 36$ & 106 & MFx,CA \\
\hline
\end{tabular}

\section{Equipment}

GB Gravity Core (Big) 2,400 lb weightstand

P Piston core (2,400 lb weightstand)

TC Trigger core (part of piston core system)

\section{Subsamples}

$\begin{array}{cl}\text { CA } & \text { Core Catcher } \\ \text { CC } & \text { Core Cutter } \\ \text { MFs } & \text { microfauna surface sample } \\ \text { MFx } & \text { scrape of external pipe for microfauna } \\ \text { Tx } & \text { Texture sample } \\ \text { WSs } & \text { scrapings from weightstand head } \\ \text { NR } & \text { No recovery in main liner }\end{array}$

SESAR_ISGN identifiers are assigned through the System for Earth SAmple Registration (SESAR): http://www.geosamples.org/ 


\section{Ship Operations}

A summary chronology of joint mission activities is presented in table 4 .

Table 4. Chronology of ship operations during conduct of HLY1002 and LSSL2012.

[In column 1: 1, Healy was operating as a single vessel; 2, joint operations with Healy leading; 3, joint operations with Louis leading. DOY, Day of Year; EEZ,

Exclusive Economic Zone; SOL, start of line; EOL, end of line; WP, way point; CTD, conductivity-temperature-depth; SVP, sound-velocity profile.]

\begin{tabular}{|c|c|c|c|c|c|c|c|c|c|c|c|}
\hline \multicolumn{10}{|c|}{$\begin{array}{l}\text { Joint U.S.-Canada } 2010 \text { Arctic UNCLOS } \\
\text { Program }\end{array}$} & \multicolumn{2}{|c|}{ Rev 11/7/2011 } \\
\hline & $\begin{array}{c}\text { Day } \\
\text { of } \\
\text { Week }\end{array}$ & $\begin{array}{c}\text { Local } \\
\text { Day }\end{array}$ & $\begin{array}{l}\text { Local } \\
\text { DOY }\end{array}$ & $\begin{array}{l}\text { Local } \\
\text { Time }\end{array}$ & $\begin{array}{l}\text { UTC } \\
\text { DOY }\end{array}$ & $\begin{array}{l}\text { UTC } \\
(\mathbf{z})\end{array}$ & $\begin{array}{l}\text { UTC } \\
\text { Delta }\end{array}$ & Vessel & Mission Chronology & $\begin{array}{l}\text { Latitude } \\
\quad \mathrm{N} .\end{array}$ & $\begin{array}{l}\text { Longitude } \\
\text { W. }\end{array}$ \\
\hline 1 & $\mathrm{M}$ & 2-Aug & 214 & $15: 00$ & 214 & 23:00 & -8 & Healy & Healy departs Dutch Harbor & & \\
\hline 1 & $\mathrm{~W}$ & 4-Aug & 216 & $16: 00$ & 216 & 21:00 & -5 & Louis & Louis crew exchange complete, Kugluktuk & & \\
\hline 1 & $\mathrm{Tu}$ & 5-Aug & 217 & & 217 & & -5 & Louis & Louis at anchor, Kugluktuk & & \\
\hline 1 & $\mathrm{~F}$ & 6-Aug & 218 & $12: 00$ & 218 & $17: 00$ & -5 & Louis & Louis underway & & \\
\hline 1 & $\mathrm{~F}$ & 6-Aug & 218 & 23:00 & 219 & $5: 00$ & -6 & Louis & Retard clocks one hour & & \\
\hline 1 & Sa & 7-Aug & 219 & $16: 23$ & 220 & $0: 23$ & -8 & Healy & $\begin{array}{l}\text { Cross - } 141 W \text {; commence hydrographic survey of U.S.-Canada } \\
\text { zone of mutual interest }\end{array}$ & $70.55317^{\circ}$ & $141.00000^{\circ}$ \\
\hline 1 & $\mathrm{Su}$ & 8-Aug & 220 & $13: 13$ & 220 & $20: 13$ & -7 & Louis & SOL 1 deploy seismic gear open-water survey Canadian EEZ & $71.18500^{\circ}$ & $135.71333^{\circ}$ \\
\hline 1 & $\mathrm{Su}$ & 8-Aug & 220 & 18:00 & 221 & $1: 00$ & -7 & Healy & Advance clocks one hour & & \\
\hline 1 & $\mathrm{Su}$ & 8-Aug & 220 & 23:00 & 221 & 6:00 & -7 & Louis & Retard clocks one hour & & \\
\hline 1 & $\mathrm{Tu}$ & $\begin{array}{r}10- \\
\text { Aug }\end{array}$ & 222 & $8: 35$ & 222 & $15: 35$ & -7 & Louis & EOL 5 recover seismic gear open-water survey Canadian EEZ & $71.31417^{\circ}$ & $136.99250^{\circ}$ \\
\hline 1 & $\mathrm{Tu}$ & $\begin{array}{r}10- \\
\text { Aug }\end{array}$ & 222 & $17: 30$ & 223 & $0: 30$ & -7 & both & $\begin{array}{l}\text { Rendezvous; Capt. Meeting ( } 2 \text { hours); transfer personnel; } \\
\text { proceed in convoy toward U.S. EEZ }\end{array}$ & & \\
\hline 1 & $\mathrm{~W}$ & $\begin{array}{l}10- \\
\text { Aug }\end{array}$ & 222 & $22: 54$ & 223 & $5: 54$ & -7 & Healy & $\begin{array}{l}\text { Cross - } 141 \mathrm{~W} \text {; finish hydrographic survey of U.S.-Canada zone of } \\
\text { mutual interest; continue convoy }\end{array}$ & $70.89583^{\circ}$ & $141.00000^{\circ}$ \\
\hline
\end{tabular}




\begin{tabular}{|c|c|c|c|c|c|c|c|c|c|c|c|}
\hline \multicolumn{10}{|c|}{$\begin{array}{l}\text { Joint U.S.-Canada } 2010 \text { Arctic UNCLOS } \\
\text { Program }\end{array}$} & \multicolumn{2}{|c|}{ Rev 11/7/2011 } \\
\hline & $\begin{array}{c}\text { Day } \\
\text { of } \\
\text { Week }\end{array}$ & $\begin{array}{l}\text { Local } \\
\text { Day }\end{array}$ & $\begin{array}{l}\text { Local } \\
\text { DOY }\end{array}$ & $\begin{array}{l}\text { Local } \\
\text { Time }\end{array}$ & $\begin{array}{l}\text { UTC } \\
\text { DOY }\end{array}$ & $\begin{array}{l}\text { UTC } \\
(\mathbf{z})\end{array}$ & $\begin{array}{l}\text { UTC } \\
\text { Delta }\end{array}$ & 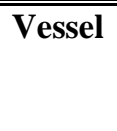 & "Mission Chronology & $\begin{array}{l}\text { Latitude } \\
\quad \mathrm{N} .\end{array}$ & $\begin{array}{l}\text { Longitude } \\
\text { W. }\end{array}$ \\
\hline 1 & $\mathrm{~W}$ & $\begin{array}{r}11- \\
\text { Aug }\end{array}$ & 223 & $6: 15$ & 223 & $13: 15$ & -7 & Louis & $\begin{array}{l}\text { Accident in Louis engine room necessitates transit to } \\
\text { Tuktoyuktuk and medevac by helicopter }\end{array}$ & & \\
\hline 1 & $\mathrm{~W}$ & Aug & 223 & $6: 30$ & 223 & $13: 30$ & -7 & Healy & Proceeds alone within U.S. EEZ for sampling program & & \\
\hline 1 & $\mathrm{~W}$ & $\begin{array}{l}11- \\
\text { Aug }\end{array}$ & 223 & $13: 30$ & 223 & 20:30 & -7 & Healy & U.S. Incidental Harassment Authorization received by email & & \\
\hline 1 & $\mathrm{~W}$ & $\begin{array}{r}11- \\
\text { Aug } \\
\end{array}$ & 223 & $14: 30$ & 223 & 21:30 & -7 & Healy & 1GB-1 gravity core on bottom (depth =2,530 m) & $71.31750^{\circ}$ & $143.99833^{\circ}$ \\
\hline 1 & $\mathrm{~W}$ & $\begin{array}{l}11- \\
\text { Aug }\end{array}$ & 223 & $15: 00$ & 223 & 22:00 & -7 & Louis & $\begin{array}{l}\text { Marine Scientific Research Authorization received from U.S. } \\
\text { Dept. of State for Louis to conduct science operations in U.S. } \\
\text { EEZ }\end{array}$ & & \\
\hline 1 & $\mathrm{~W}$ & $\begin{array}{r}11- \\
\text { Aug }\end{array}$ & 223 & 19:18 & 224 & $2: 18$ & -7 & Healy & $\begin{array}{l}\text { 1P-1 piston core and 1TC-1 trigger core on bottom (depth = } \\
2,538 \mathrm{~m} \text { ) }\end{array}$ & $71.31750^{\circ}$ & $143.99967^{\circ}$ \\
\hline 1 & Th & $\begin{array}{r}12- \\
\text { Aug } \\
\end{array}$ & 224 & 4:20 & 224 & $11: 20$ & -7 & Healy & $\begin{array}{l}\text { 2P-1 piston core and 2TC- } 1 \text { trigger core on bottom (depth = } \\
1,157 \mathrm{~m} \text { ) }\end{array}$ & $70.95917^{\circ}$ & $144.05233^{\circ}$ \\
\hline 1 & Th & $\begin{array}{r}12- \\
\text { Aug }\end{array}$ & 224 & 16:07 & 224 & 23:07 & -7 & Louis & SOL 6 seismic in U.S. EEZ & $71.65667^{\circ}$ & $148.18650^{\circ}$ \\
\hline 2 & $\mathrm{~F}$ & $\begin{array}{r}13- \\
\text { Aug } \\
\end{array}$ & 225 & $7: 20$ & 225 & 14:20 & -7 & Healy & Healy joins Louis for SOL 7 & $72.26483^{\circ}$ & $145.40767^{\circ}$ \\
\hline 1 & $\mathrm{Su}$ & $\begin{array}{r}15- \\
\text { Aug }\end{array}$ & 227 & $10: 30$ & 227 & $17: 30$ & -7 & Healy & $\begin{array}{l}\text { Healy departs Louis in light ice to run to Barrow for crew and } \\
\text { parts; continuing along Line } 7 \text { for multibeam and CHIRP }\end{array}$ & & \\
\hline 1 & M & $\begin{array}{r}16- \\
\text { Aug } \\
\end{array}$ & 228 & $14: 20$ & 228 & 21:20 & -7 & Healy & $\begin{array}{l}\text { Supplies arrive Healy from Barrow; Dean Kavanaugh aboard } \\
\text { Healy; Healy departs Barrow to resume escort }\end{array}$ & $72.95650^{\circ}$ & $148.41383^{\circ}$ \\
\hline 2 & $\mathrm{Tu}$ & $\begin{array}{r}17- \\
\text { Aug }\end{array}$ & 229 & 11:30 & 229 & 18:30 & -7 & Healy & Healy joins Louis at ice edge along Line 11 & $73.40883^{\circ}$ & $150.87883^{\circ}$ \\
\hline
\end{tabular}




\begin{tabular}{|c|c|c|c|c|c|c|c|c|c|c|c|}
\hline \multicolumn{10}{|c|}{$\begin{array}{l}\text { Joint U.S.-Canada } 2010 \text { Arctic UNCLOS } \\
\text { Program }\end{array}$} & \multicolumn{2}{|c|}{ Rev 11/7/2011 } \\
\hline & $\begin{array}{c}\begin{array}{c}\text { Day } \\
\text { of } \\
\text { Week }\end{array} \\
\end{array}$ & $\begin{array}{c}\text { Local } \\
\text { Day }\end{array}$ & $\begin{array}{l}\text { Local } \\
\text { DOY }\end{array}$ & $\begin{array}{l}\text { Local } \\
\text { Time }\end{array}$ & $\begin{array}{l}\text { UTC } \\
\text { DOY }\end{array}$ & \begin{tabular}{c|} 
UTC \\
$(\mathrm{z})$
\end{tabular} & $\begin{array}{l}\text { UTC } \\
\text { Delta }\end{array}$ & Vessel & Mission Chronology & $\begin{array}{l}\text { Latitude } \\
\quad \mathrm{N} .\end{array}$ & $\begin{array}{l}\text { Longitude } \\
\text { W. }\end{array}$ \\
\hline 2 & $\mathrm{Tu}$ & $\begin{aligned} 17- \\
\text { Aug }\end{aligned}$ & 229 & $13: 45$ & 229 & $20: 45$ & -7 & Healy & $\begin{array}{l}\text { Dean Kavanaugh and fuel filters depart Healy via helicopter en } \\
\text { route to Louis }\end{array}$ & & \\
\hline 2 & $\mathrm{Tu}$ & $\begin{aligned} 17- \\
\text { Aug }\end{aligned}$ & 229 & $22: 50$ & 230 & $5: 50$ & -7 & Louis & Louis exits U.S. EEZ & $74.18333^{\circ}$ & $150.39333^{\circ}$ \\
\hline 2 & $\mathrm{~F}$ & $\begin{aligned} 20- \\
\text { Aug }\end{aligned}$ & 232 & 8:00 & 232 & $15: 00$ & -7 & Louis & EOL 14, seismic gear recovered for transit & $76.58917^{\circ}$ & $146.41700^{\circ}$ \\
\hline 1 & $\mathrm{~F}$ & $\begin{array}{r}20- \\
\text { Aug }\end{array}$ & 232 & 9:00 & 232 & $16: 00$ & -7 & both & Both ships all stop for CTD/SVP (3 hrs) & & \\
\hline 3 & $\mathrm{~F}$ & $\begin{array}{r}20- \\
\text { Aug }\end{array}$ & 232 & $11: 45$ & 232 & $18: 45$ & -7 & Louis & Commence transit; Louis in lead & & \\
\hline 2 & Sa & $\begin{aligned} 21- \\
\text { Aug }\end{aligned}$ & 233 & 4:42 & 233 & $11: 42$ & -7 & Louis & SOL 15 , seismic gear deployed & $78.11383^{\circ}$ & $153.27267^{\circ}$ \\
\hline 2 & $\mathrm{Su}$ & $\begin{aligned} 22- \\
\text { Aug }\end{aligned}$ & 234 & $11: 00$ & 234 & 18:00 & -7 & Louis & EOL 16, seismic gear recovered for transit & $78.97467^{\circ}$ & $145.28783^{\circ}$ \\
\hline 3 & M & $\begin{array}{r}23- \\
\text { Aug }\end{array}$ & 235 & $15: 00$ & 235 & 22:00 & -7 & Louis & Commence transit; Louis in lead & & \\
\hline 1 & $\mathrm{M}$ & $\begin{array}{r}23- \\
\text { Aug }\end{array}$ & 235 & 21:30 & 236 & $4: 30$ & -7 & Louis & Louis all stop to replace port shaft bearing & & \\
\hline 1 & M & $\begin{array}{r}23- \\
\text { Aug } \\
\end{array}$ & 235 & $22: 50$ & 236 & $5: 50$ & -7 & Healy & $\begin{array}{l}\text { Healy departs escort with Louis and continues alone for seamount } \\
\text { survey }\end{array}$ & & \\
\hline 1 & $\mathrm{~W}$ & $\begin{aligned} 25- \\
\text { Aug }\end{aligned}$ & 237 & $0: 40$ & 237 & $7: 40$ & -7 & Louis & Louis underway to rendezvous Healy (down 27 hours) & & \\
\hline 1 & $\mathrm{~W}$ & $\begin{aligned} 25- \\
\text { Aug }\end{aligned}$ & 237 & $10: 46$ & 237 & $17: 46$ & -7 & Healy & $\begin{array}{l}\text { 3P-1 piston core and 3TC-1 trigger core on bottom (depth = } \\
3,070 \mathrm{~m})\end{array}$ & $81.57133^{\circ}$ & $134.47783^{\circ}$ \\
\hline 1 & Th & $\begin{array}{r}26- \\
\text { Aug }\end{array}$ & 238 & 3:00 & 238 & $10: 00$ & -7 & both & Rendezvous WP28 for W-E line & $82.53000^{\circ}$ & $139.17833^{\circ}$ \\
\hline 2 & Th & $\begin{array}{r}26- \\
\text { Aug } \\
\end{array}$ & 238 & 4:30 & 238 & $11: 40$ & -7 & Louis & SOL 17 , Healy in lead & $82.54450^{\circ}$ & $138.93050^{\circ}$ \\
\hline 1 & $\mathrm{~F}$ & $\begin{array}{r}27- \\
\text { Aug } \\
\end{array}$ & 239 & 8:00 & 239 & $15: 30$ & -7 & both & Louis retrieve seismic gear; all stop for CTD/SVP (5 hours) & $81.78500^{\circ}$ & $128.30667^{\circ}$ \\
\hline 1 & $\mathrm{~F}$ & $\begin{array}{r}27- \\
\text { Aug }\end{array}$ & 239 & 15:00 & 239 & $22: 00$ & -7 & Louis & Louis retrieve seismic gear and repair; all stop (5 hours) & & \\
\hline 3 & $\mathrm{~F}$ & $27-$ & 239 & 20:00 & 240 & 3:30 & -7 & both & Underway for bathymetric program, Louis in lead & & \\
\hline
\end{tabular}




\begin{tabular}{|c|c|c|c|c|c|c|c|c|c|c|c|}
\hline \multicolumn{10}{|c|}{$\begin{array}{l}\text { Joint U.S.-Canada } 2010 \text { Arctic UNCLOS } \\
\text { Program }\end{array}$} & \multicolumn{2}{|c|}{ Rev 11/7/2011 } \\
\hline & $\begin{array}{c}\text { Day } \\
\text { of } \\
\text { Week }\end{array}$ & $\begin{array}{c}\text { Local } \\
\text { Day }\end{array}$ & $\begin{array}{l}\text { Local } \\
\text { DOY }\end{array}$ & $\begin{array}{l}\text { Local } \\
\text { Time }\end{array}$ & $\begin{array}{l}\text { UTC } \\
\text { DOY }\end{array}$ & $\begin{array}{c}\text { UTC } \\
\text { (z) }\end{array}$ & $\begin{array}{l}\text { UTC } \\
\text { Delta }\end{array}$ & Vessel & Mission Chronology & $\begin{array}{l}\text { Latitude } \\
\quad \mathrm{N} .\end{array}$ & $\begin{array}{l}\text { Longitude } \\
\text { W. }\end{array}$ \\
\hline & & Aug & & & & & & & & & \\
\hline 3 & Sa & $\begin{array}{r}28- \\
\text { Aug }\end{array}$ & 240 & $6: 11$ & 240 & 13:11 & -7 & Healy & Healy enters Canadian EEZ for MB bathymetry & $81.38517^{\circ}$ & $122.99250^{\circ}$ \\
\hline 3 & Sa & $\begin{array}{r}28- \\
\text { Aug }\end{array}$ & 240 & $18: 00$ & 241 & $1: 00$ & -7 & both & $\begin{array}{l}\text { WP } 29 \text { in Canadian EEZ; health issue reported for steward } \\
\text { aboard Louis - diverting S for medevac; Louis in lead with Healy } \\
\text { following }\end{array}$ & $80.98167^{\circ}$ & $119.07333^{\circ}$ \\
\hline 1 & $\mathrm{Su}$ & $\begin{aligned} 29- \\
\text { Aug }\end{aligned}$ & 241 & & 241 & & -7 & both & Continue transit, vessels trade lead & & \\
\hline 1 & $\mathrm{M}$ & $\begin{array}{r}30- \\
\text { Aug }\end{array}$ & 242 & $0: 47$ & 242 & $7: 47$ & -7 & Healy & Healy departs Canadian EEZ & $79.51883^{\circ}$ & $131.64900^{\circ}$ \\
\hline 1 & M & $\begin{array}{r}30- \\
\text { Aug }\end{array}$ & 242 & & 242 & & -7 & both & Continue transit, vessels trade lead & & \\
\hline 1 & M & $\begin{array}{r}30- \\
\text { Aug }\end{array}$ & 242 & $9: 45$ & 242 & $16: 45$ & -7 & both & Vessels prepare to separate & & \\
\hline 1 & M & $\begin{array}{r}30- \\
\text { Aug }\end{array}$ & 242 & 9:45 & 242 & $16: 45$ & -7 & Healy & $\begin{array}{l}\text { Injury reported on Healy - crew member will require medical } \\
\text { evacuation; vessels continue to convoy for U.S./Canada mainland }\end{array}$ & & \\
\hline 1 & $\mathrm{M}$ & $\begin{array}{r}30- \\
\text { Aug }\end{array}$ & 242 & $11: 15$ & 242 & 18:15 & -7 & Healy & $\begin{array}{l}\text { Injured Healy crew member transferred by launch to Louis for } \\
\text { evacuation; Healy diverts for coring ops in E. Beaufort }\end{array}$ & & \\
\hline 1 & $\mathrm{M}$ & $\begin{array}{r}30- \\
\text { Aug }\end{array}$ & 242 & $15: 20$ & 242 & $22: 20$ & -7 & Healy & Skirts Canadian EEZ; maximum incursion $<1 \mathrm{nmi}$ & & \\
\hline 1 & M & Aug & 242 & $18: 26$ & 243 & $1: 26$ & -7 & Healy & Skirts Canadian EEZ; maximum incursion $<1 \mathrm{nmi}$ & & \\
\hline 1 & $\mathrm{Tu}$ & $\begin{array}{r}31- \\
\text { Aug }\end{array}$ & 243 & $11: 05$ & 243 & $18: 05$ & -7 & Healy & $\begin{array}{l}\text { 4P-1 piston core and 4TC-1 trigger core on bottom (depth }= \\
3,700 \mathrm{~m})\end{array}$ & $75.58417^{\circ}$ & $140.09283^{\circ}$ \\
\hline 1 & $\mathrm{Tu}$ & $\begin{array}{r}31- \\
\text { Aug }\end{array}$ & 243 & 18:30 & 244 & $1: 30$ & -7 & Louis & $\begin{array}{l}\text { Medical evacuation of sick and injured crew members to } \\
\text { Tuktoyuktuk by helicopter }\end{array}$ & $70.25000^{\circ}$ & $133.75000^{\circ}$ \\
\hline 1 & $\mathrm{Tu}$ & $\begin{array}{r}31- \\
\text { Aug } \\
\end{array}$ & 243 & $22: 23$ & 244 & $5: 23$ & -7 & Healy & Healy enters Canadian EEZ for multibeam and sampling & $74.72867^{\circ}$ & $137.41100^{\circ}$ \\
\hline 1 & $\mathrm{~W}$ & 1-Sep & 244 & $1: 00$ & 244 & 8:00 & -7 & Louis & Underway from Tuktoyuktuk to rejoin Healy & & \\
\hline
\end{tabular}




\begin{tabular}{|c|c|c|c|c|c|c|c|c|c|c|c|}
\hline \multicolumn{10}{|c|}{$\begin{array}{l}\text { Joint U.S.-Canada } 2010 \text { Arctic UNCLOS } \\
\text { Program }\end{array}$} & \multicolumn{2}{|c|}{ Rev 11/7/2011 } \\
\hline & $\begin{array}{c}\text { Day } \\
\text { of } \\
\text { Week }\end{array}$ & $\begin{array}{c}\text { Local } \\
\text { Day }\end{array}$ & $\begin{array}{l}\text { Local } \\
\text { DOY }\end{array}$ & $\begin{array}{l}\text { Local } \\
\text { Time }\end{array}$ & $\begin{array}{l}\text { UTC } \\
\text { DOY }\end{array}$ & $\begin{array}{l}\text { UTC } \\
(\mathbf{z})\end{array}$ & $\begin{array}{l}\text { UTC } \\
\text { Delta }\end{array}$ & Vessel & "Mission Chronology & $\begin{array}{l}\text { Latitude } \\
\quad \text {. }\end{array}$ & $\begin{array}{l}\text { Longitude } \\
\text { W. }\end{array}$ \\
\hline 1 & $\mathrm{~W}$ & 1-Sep & 244 & 21:00 & 245 & 4:00 & -7 & Louis & Louis enters heavy ice on return transit & & \\
\hline 1 & Th & 2-Sep & 245 & $11: 36$ & 245 & $18: 36$ & -7 & Healy & $\begin{array}{l}\text { 5P-1 piston core and 5TC- } 1 \text { trigger core on bottom (depth }=2081 \\
\text { m) }\end{array}$ & $76.54383^{\circ}$ & $128.62750^{\circ}$ \\
\hline 1 & Th & 2-Sep & 245 & 18:15 & 246 & 1:15 & -7 & both & Vessels rendezvous; Dept. of Homeland Security flyover & $76.53517^{\circ}$ & $128.72750^{\circ}$ \\
\hline 2 & Th & 2-Sep & 245 & 19:00 & 246 & $2: 00$ & -7 & both & Deploy seismic gear, Healy in lead & & \\
\hline 1 & Sa & 4-Sep & 247 & $12: 00$ & 247 & 19:00 & -7 & Healy & Healy breaks off joint program to head to Barrow & & \\
\hline 1 & Sa & 4-Sep & 247 & 13:19 & 247 & 20:19 & -7 & Healy & Healy departs Canadian EEZ & $75.77900^{\circ}$ & $136.76417^{\circ}$ \\
\hline 1 & Sa & 4-Sep & 247 & $17: 00$ & 248 & $1: 00$ & -8 & Healy & Change clocks to Alaskan daylight time zone & & \\
\hline 1 & Mo & 6-Sep & 249 & 4:00 & 249 & 12:00 & -8 & Healy & Arrive Barrow & & \\
\hline 1 & $\mathrm{~W}$ & $\begin{array}{l}14- \\
\text { Sep }\end{array}$ & 257 & $16: 00$ & 257 & 21:00 & -5 & Louis & Arrive Kugluktuk for disembarkation & & \\
\hline
\end{tabular}




\section{Data and Metadata}

Extensive information regarding cruise HLY1002 (USGS Field Activity ID H-03-10-AR), including links to reports, articles, and blogs, is available at http://walrus.wr.usgs.gov/infobank/h/h310ar/html/h-3-10-ar.meta.html

All raw data from the cruise are archived at the National Geophysical Data Center (NGDC) through the Rolling Deck to Repository initiative. Complete file manifests and other metadata are available at:

http://www.rvdata.us/catalog/HLY1002

http://get.rvdata.us/services/cruise/HLY1002.xml

Raw and processed multibeam data and metadata, as well as raw CHIRP subbottom data in SEG-Y format are posted on the NGDC's ECS data page at http://ngdc.noaa.gov/mgg/ecs/cruises.html. These data are also cross-posted at the Law of the Sea project's Web site at the Center for Coastal and Ocean Mapping of the University of New Hampshire's Law of the Sea repository at http://ccom.unh.edu/theme/law-sea/arctic-ocean.

IMPORTANT NOTE: Under terms of the Memorandum of Understanding between the USGS and the GSC, the swath-bathymetry and subbottom profile data acquired during cruise HLY1002 within the Canadian 200-nmi-wide Exclusive Economic Zone (EEZ) are proprietary, and public release is not presently authorized. The trackline segments that fall within the Canadian EEZ are listed in table 5.

Table 5. Time periods during which the Healy bathymetry and CHIRP subbottom data are embargoed until further notice.

\begin{tabular}{|c|c|c|c|l|c|c|}
\hline Day & $\begin{array}{c}\text { Date } \\
\text { (UTC) }\end{array}$ & $\begin{array}{c}\text { Julian } \\
\text { day }\end{array}$ & $\begin{array}{c}\text { UTC (Hour: } \\
\text { Minute) }\end{array}$ & \multicolumn{1}{|c|}{ Comment } & Latitude N. & Longitude W. \\
\hline Sa & 28-Aug & 240 & $13: 11$ & $\begin{array}{l}\text { Healy enters Canadian EEZ } \\
\text { for multibeam bathymetry. }\end{array}$ & $81.38517^{\circ}$ & $122.99250^{\circ}$ \\
\hline $\mathrm{M}$ & 30-Aug & 242 & $7: 47$ & Healy leaves Canadian EEZ. & $79.51883^{\circ}$ & $131.64900^{\circ}$ \\
\hline $\mathrm{Tu}$ & 31-Aug & 244 & $5: 23$ & $\begin{array}{l}\text { Healy enters Canadian EEZ } \\
\text { for multibeam bathymetry and } \\
\text { sampling. }\end{array}$ & $74.72867^{\circ}$ & $137.41100^{\circ}$ \\
\hline Sa & 4-Sep & 247 & $20: 19$ & Healy leaves Canadian EEZ. & $75.77900^{\circ}$ & $136.76417^{\circ}$ \\
\hline
\end{tabular}




\section{Public Outreach}

Three members of the scientific party performed outreach duties, principally by writing expedition logs for different websites. Helen Gibbons (USGS) wrote for the ECS Project Web site (http://continentalshelf.gov/missions/10arctic/). Additional logs were written by two teachers on the scientific crew. William Schmoker, an Earth Science teacher at Centennial Middle School in Boulder, Colorado, joined the expedition through PolarTREC (http://www.polartrec.com/), a program that links teachers with researchers for hands-on field research in polar regions. Caroline Singler, an Earth Science and Aquatic Biology teacher at Lincoln Sudbury Regional High School in Sudbury, Massachusetts, joined the expedition through the National Oceanic and Atmospheric Administration (NOAA) Teacher at Sea program (http://teacheratsea.noaa.gov/), which places teacher-participants on research cruises run by NOAA and its partner agencies, such as the USGS.

Caroline Singler's log entries are available at http://csinglertas.blogspot.com/. In addition to teaching high school classes, Caroline coaches a National Ocean Sciences Bowl (NOSB) team, whose members followed her logs while she was at sea. Caroline's Earth Science class began near the end of the cruise, on August 31, 2010, allowing her to send a welcome from the Arctic to her new students. She used her log entries and data from the cruise in school exercises and NOSB coaching during the school year.

Bill Schmoker's log entries are posted at http://www.polartrec.com/member/bill-schmoker. Before the cruise, Bill was interviewed by a radio station and two newspapers in the Boulder area, alerting the community to the upcoming expedition and inviting them to follow his logs. Bill's Earth Science class began on August 18, 2010, giving the students about 21/2 weeks to follow his log in nearreal time from the Arctic. Bill also coordinated an event called PolarConnect: With the help of PolarTREC, his assistant principal, and the Coast Guard, he called Centennial Middle School from the Healy on August 31, 2010, spoke to two groups of about 300 students each, and engaged the students in question-and-answer sessions about the Arctic and his experiences there.

In addition to posting logs, the teachers assisted with watchstanding in the geophysics lab, processing sediment cores for storage, and collecting water subsamples for analysis aboard the Healy and at onshore labs. Their participation in the expedition provided practical help to the researchers onboard and spread information about the cruise and the ECS Project to students, teachers, parents, and the public in their communities.

\section{Acknowledgments}

We thank the entire crew of the USCG Cutter Healy, in particular Commanding Officer Captain William (Bill) J. Rall, Operations Officer Lieutenant Commander Eric St. Pierre, and Executive Officer Commander John Reeves. We are grateful for the planning and logistical support provided by David Forcucci, USCG liaison in Seattle.

We appreciate the dedication and expertise provided by the Healy technical-support team of Dale Chayes, Steve Roberts, and Tom Bolmer, who compiled the cruise data synopsis in appendix B. Bernie Coakley (University of Alaska, Fairbanks) processed the gravity data and provided the crossover analysis listed in table 2.

Florence Wong and Ray Sliter, USGS, reviewed the report.

This program was conducted under the auspices of the U.S. Extended Continental Shelf Task Force (http://www.continentalshelf.gov/). 


\section{References Cited}

Childs, J.R., Triezenberg, P.J., and Danforth, W.W., 2012, 2008 Joint United States-Canadian Program to explore the limits of the Extended Continental Shelf aboard the U.S. Coast Guard Cutter HealyCruise HLY0806: U.S. Geological Survey Open-File Report 2012-1210, 15 p. and appendixes. (Also available at http://pubs.usgs.gov/of/2012/1210/.)

Coakley, Bernard, Kristoffersen, Yngve, and Hopper, John, 2005, Cruise report for underway geophysics program HLY 05-03 5-5 August 2005; Dutch Harbor, Alaska to 30 September, 2005; Tromso, Norway: Report to the U.S. National Science Foundation, 84 p., accessed February 13, 2012,

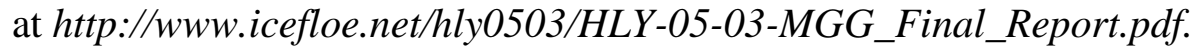

Edwards, B.D., Saint-Ange, Frankie, Pohlman, John, Higgins, Jenna, Mosher, D.C., Lorenson, T.D., and Hart, Patrick, 2011, Sedimentology of cores recovered from the Canada Basin of the Arctic Ocean, Abstract PP33A-1915: Presented at 2011 Fall Meeting, American Geophysical Union, San Francisco, Calif., December 5-9, 2011

Grantz, Arthur, Hart, P.E., and May, S.D., 2004, Seismic reflection and refraction data acquired in Canada Basin, Northwind Ridge and Northwind Basin, Arctic Ocean in 1988, 1992 and 1993: U.S. Geological Survey Open-File Report 2004-1243. (Also available at http://pubs.usgs.gov/of/2004/1243/.)

Grantz, Arthur, May, S.D., and Mann, D.M., 1982, Tracklines of multichannel seismic-reflection data collected in the Beaufort and Chukchi Seas in 1977 for which demultiplexed field tapes are available from the U.S. Geological Survey: U.S. Geological Survey Open-File Report 82-651, 1 pl.

Hart, P.E., Pohlman, J.W., Lorenson, T.D., and Edwards, B.D., 2011, Beaufort Sea deep-water gas hydrate recovery from a seafloor mound in a region of widespread BSR occurrence: Proceedings of the 7th International Conference on Gas Hydrates (ICGH 2011), Edinburgh, Scotland, United Kingdom, July 17-21, 2011.

Hutchinson, D.R., Jackson, H.R., Shimeld, J.W., Chapman, C.B., Childs, J.R., Funck, T., and Rowland, R.W., 2009, Acquiring marine data in the Canada Basin, Arctic Ocean: EOS, Transactions, American Geophysical Union, v. 90, no. 23, p. 198-198.

Jackson, H.R., and DesRoches, K.J., 2010, 2008 Louis S. St-Laurent field report, August 22-October 3, 2008, Geological Survey of Canada, Open File 6275, 184 p., accessed February 13, 2013, a ftp://ftp2.cits.rncan.gc.ca/pub/geott/ess_pubs/285/285359/of_6275.pdf.

Kongsberg, 2010, Kongsberg EM series multibeam echo sounder, EM datagram formats: Kongsburg, Norway, Kongsberg Maritime AS, September 2010, 103 p., accessed March 13, 2013, at http://www.km.kongsberg.com/ks/web/nokbg0397.nsf/AllWeb/253E4C58DB98DDA4C1256D7900483 73B/\$file/160692_em_datagram_formats.pdf.

Mayer, L.A., 2003, Cruise report-U.S. Law of the Sea cruise to map the foot of the slope and 2500-m isobath of the U.S. Arctic Ocean margin-Barrow, AK to Barrow. AK, August 30 to September 11, 2003: Durham, N.H., University of New Hampshire Center for Coastal and Ocean Mapping-Joint Hydrographic Center, 19 p., accessed February 14, 2013, at http://ccom.unh.edu/sites/default/files/publications/Mayer_03_cruise_report_HE-0302.pdf.

Mayer, L.A., 2004, Cruise report-U.S. Law of the Sea cruise to map theFfoot of the slope and 2500-m isobath of the U.S. Arctic Ocean margin- Nome, AK to Barrow, AK, October 6 to October 26, 2004: Durham, N.H., University of New Hampshire Center for Coastal and Ocean Mapping -Joint Hydrographic Center, 47 p., accessed February 14, 2012, at http://ccom.unh.edu/sites/default/files/publications/Mayer_04_cruise_report_HE-0405.pdf.

Mayer, L.A., and Armstrong, A.A., 2007, Cruise report-U.S. Law of the Sea cruise to map the foot of the slope and 2500-m Isobath of the U.S. Arctic Ocean margin-Barrow, AK to Barrow. AK, August 17 to September 15, 2007: Durham, N.H., University of New Hampshire Center for Coastal and 
Ocean Mapping-Joint Hydrographic Center, 182 p., accessed February 14, 2013, at http://ccom.unh.edu/sites/default/files/publications/Mayer_07_cruise_report_HE-0703.pdf.

Mayer, L.A., and Armstrong, A.A., 2008, Cruise report-U.S. Law of the Sea cruise to map the foot of the slope and 2500-m isobath of the U.S. Arctic Ocean margin-Barrow, AK to Barrow, AK, August 14 to September 5, 2008: Durham, N.H., University of New Hampshire, Center for Coastal and Ocean Mapping-Joint Hydrographic Center, 179 p., accessed February 14, 2013, at http://ccom.unh.edu/sites/default/files/publications/Mayer_08_HEALY_0805_CRUISERPT.pdf.

Mayer, L.A., and Armstrong, A.A., 2009, Cruise report-U.S. Law of the Sea cruise to map the foot of the slope and 2500-m isobath of the US Arctic Ocean margin-Barrow, AK to Barrow, AK, August 7 to September 16, 2009 : Durham, N.H., University of New Hampshire Center for Coastal and Ocean Mapping-Joint Hydrographic Center, 118 p., accessed February 14, 2013, at http://ccom.unh.edu/sites/default/files/publications/Mayer_2009_cruise_report_HE0905.pdf.

Mayer, L.A. and Armstrong, A.A., 2011, Cruise report-U.S. Law of the Sea cruise to map the foot of the slope and 2500-m isobaths of the U.S. Arctic Ocean margin-Barrow, AK to Dutch Harbor, AK, August 15 to September 28, 2011: Durham, N.H., University of New Hampshire Center for Coastal and Ocean Mapping-Joint Hydrographic Center, 235 p., accessed February 14, 2013, at http://ccom.unh.edu/sites/default/files/publications/Mayer_2011_cruise_report_HEALY1102.pdf.

Mosher, D.C., ed., 2012, 2011 Canadian high Arctic Seismic Expedition-CCGS Louis S. St-Laurent cruise report: Geological Survey of Canada, Open File 7053; 290 p., doi: 10.4095/290241, accessed March 13, 2013, at ftp://ftp2.cits.rncan.gc.ca/pub/geott/ess_pubs/290/290241/of_7053.pdf.

Mosher, D.C., Shimeld, J.W., Chapman, C.B., 2011, 2010 Canada Basin seismic reflection and refraction survey, western Arctic Ocean-CCGS Louis S. St-Laurent expedition report: Geological Survey of Canada, Open File 6720; 252 p., accessed March 13, 2013, at [ftp://ftp2.cits.rncan.gc.ca/pub/geott/ess_pubs/288/288024/of_6720.pdf].

Mosher, D.C., Shimeld, J.W., and Hutchinson, D.R., 2009, 2009 Canada Basin seismic reflection and refraction survey, western Arctic Ocean-CCGS Louis S. St-Laurent expedition report: Geological Survey of Canada, Open File 6343, 266 p., accessed March 13, 2013, at ftp://ftp2.cits.rncan.gc.ca/pub/geott/ess_pubs/248/248208/of_6343.pdf].

Wan, Elmyra, McGann, M.L., and Edwards, B.D., 2011, Preliminary planktic and benthic foraminiferal biostratigraphy of cores from the Canada Basin, western Arctic Ocean, Abstract PP33A-1916:

Presented at 2011 Fall Meeting, American Geophysical Union, San Francisco, Calif., December 5-9, 2011. 


\section{Appendices}

Appendixes can be accessed and downloaded at http://pubs.usgs.gov/of/2013/1067.

Appendix A. Cruise-level Metadata

Appendix B. Data Synopsis (Chayes, Bolmer and Roberts)

Appendix C. Digital Data Formats

Appendix D. Geophysical Watchstander E-logs

Appendix E. Coring Operations Deck Logs

Appendix F. Water Sampling and Ocean Acidification Measurements

Appendix G . Protected Species Observer Report

Appendix H. Polar Bear Interaction Plan 